\title{
A General Review of Scientific Studies Carried Out in Turkey Relating to History of India
}

\section{Türkiye'de Hindistan Tarihi Üzerine Yapılan Bilimsel Çalışmalara Dair Genel Bir Değerlendirme}

\author{
H. Hilal ȘAHİN ${ }^{1}$ (1)
}

${ }^{1}$ Corresponding author/Sorumlu yazar: H. Hilal Şahin (Asst. Prof. Dr.), Giresun University, Faculty of Science and Literature, Department of History, Giresun, Turkey

E-posta: hilalcaglayan@yahoo.com, hilal.sahin@giresun.edu.tr

ORCID: 0000-0002-3192-4658

Submitted/Başvuru: 31.08.2019

Revision Requested/Revizyon Talebi:

14.10.2019

Last Revision Received/Son Revizyon:

05.11.2019

Accepted/Kabul: 10.11.2019

Published Online/Online Yayın: 31.01.2020

Citation/Atıf: Sahin, H. Hilal. "A General Review of Scientific Studies Carried Out in Turkey Relating to History of India." Türkiyat Mecmuas-Journal of Turkology 30, 1 (2020): 231-268. https://doi.org/10.26650/iuturkiyat.682780

\begin{abstract}
Studies on India in Turkey began with the establishment of the Chair of Indology in 1936 within the structure of the Faculty of Language, History and Geography at Ankara University (DTCF) under the guidance of Mustafa Kemal Ataturk. Walter Ruben (1899-1982), the founder of this chair, carried out several studies in the field of Indian literature and history by making great contributions to developing Indology in our country, with the identification and evaluation of sections about Turks in Indian sources. Built on a strong foundation, this field of science provided that a great deal of scientific treatises were presented in the light of Indian sources at great effort by Indologists and historians such as Abidin İtil and Kemal Çağdaş, who had raised been following Ruben. In this regard, studies that are carried out in Turkey on the Turkish period which has left its mark on India are continuing in the context of Indian studies. Therefore, this study aims to evaluate general studies particularly carried out in the area of the History of Turks in India in Turkey and also to present the translated works made in this area, Turkish studies, dissertations for Higher Education and the relevant articles. In the study, we made some determinations and suggestions for the relevant area and we used explanations, comparisons and sampling methods.
\end{abstract} Keywords: India, Indian, Indian Turkish History, mughal, baburids, Indology

\section{ÖZ}

Türkiye'de Hindistan ile ilgili araştırmalar Mustafa Kemal Atatürk'ün öncülüğünde 1936 yılında Ankara Üniversitesi Dil ve Tarih Coğrafya Fakültesi (DTCF) bünyesinde Hindoloji kürsüsünün kurulmasıyla başlatılmıştır. Bu kürsünün kurucusu Walter Ruben (1899-1982), ülkemizde Hindoloji alanının gelişmesine büyük katkılar sunarak Hint kaynaklarında yer alan Türklerle ilgili bölümlerin belirlenmesi ve değerlendirilmesi ile Hint edebiyatı ve tarihi alanında pek çok araştırmalar gerçekleştirmiştir. Temeli sağlam bir şekilde atılan bu bilim dalı; Ruben'den sonra yetişen Abidin İtil, Kemal Çağdaş gibi Hindolog ve tarihçilerin büyük çabalarıyla Hint kaynakları ışı̆ında pek çok bilimsel eserler ortaya konulmasını sağlamıştır. Bu bağlamda Hindistan'a damgasını vuran Türk dönemi hakkında da Türkiye'de yapılan çalışmalar Hindistan araştırmaları bağlamında devam etmektedir. Dolayısıyla bu çalışmamız bilhassa Türklerin Hindistan'daki Tarihi 
üzerine Türkiye'de yapılan çalışmaları genel olarak değerlendirmeyi amaçlamış olup bu sahada yapılan çeviri eserleri, Türkçe çalışmaları, Yüksek öğretim tezlerini ve ilgili makaleleri de ortaya koymayı amaçlamıştır. Araştırmada saha ile ilgili tespitler ve önerilerde bulunulmuş olup yöntem olarak açılama, karşılaştırma ve örnekleme metotları kullanılmıştır. Anahtar kelimeler: Hindistan, Hint, Hindistan Türk Tarihi, mughal, babürlüler, Hindoloji 


\section{Introduction}

"We have brought a new religion to Hind; we have presented a new language. We are the Baburids, we are Ekber. The West has learned from us the important tales of Hind. The Hümâyunnâme is translated into all the languages of Europe. We do not recognize India. We don't recognize it despite the three large volumes of history books by Hikmet Bayur" Cemil Meriç

The purpose of this article is to make some observations and evaluations of studies carried out on Indian history and culture in Turkey. However, we do not aim to cover the complete bibliography on this topic. Rather, we want to reach some conclusions, highlighting only certain publications on Indian Turkish history, as part of a Turkish Worlds studies in Turkey.

India, having one of the earliest and richest civilizations of the world has had an impact on world history, culture and civilization with its rich and rooted culture, and has become an ageless center of interest for centuries for people with its ancient past. Therefore, India is a civilization that has attracted the attention of the entire world throughout civilization history, experienced continuous invasions and that has, however, achieved its richness by engulfing the cultures into it, instead of further disappearing in the face of each new invasion. Through the dynamics of this cultural heritage, India has always been able to keep its existence alive on its path from the past to the future.

Turks had important roles in Islamizing India and developing Indian-Islamic culture and civilization. Great Islamic scholars living in this region and all works by them went in parallel with each other due to the existence of Muslim-Turkish states. In addition, the most important issue which attracted the attention of travellers who came to India, is Indian-Turkish architecture. The Urdu language, Turkish words in Hindi languages and the presence of independent Muslim states (Pakistan, Afghanistan and Bangladesh) on the peninsula are also manifestations of Turks' impact on and permanence in the region, as well.

Even though Turks had been seen from the first ages in India, the arrival of Islamism into India started with the conquests of Sindh by Muhammad-Bin-Qasim during the Umayyad period. But, the permanence of Islamism in the region started with the Muslim-Turkish Ghaznavid State (1001-1187) and it continued until the Baburid State (1526-1858) handed over the domination of the region to the British. Muslim domination here continued from the $12^{\text {th }}$ century to the $19^{\text {th }}$ century and in this context, sovereignty was administered by Turkish states and almost all religious, scientific, architectural, cultural and social activities were developed thanks to the said Muslim-Turkish states. It should be accepted that each socio-cultural heritage in India is a product by the Indian and the Turkish-until British invasion - when it is thought that "India is mother and

1 Cemil Meriç, Hint Edebiyatı (Indian Literature), (İstanbul: Dönem Yayınları, 1964), 7-8. 
one of two children is Turks, other is Indians" as Mahathma Gandhi (1869-1948) had stated. ${ }^{2}$ In this context, examining Turks' position in Indian history is of importance. In respect of hereof, the mention of India in Turkish historiography is worthy of note in terms of both the subject and examination area.

Based on this, our study includes our suggestions and determinations as well as giving a place to emphasize which works have presented the matter, addressing Indian history studies in Turkey, and to the situation of studies which were carried out in the field.

\section{Studies on India (Indian) Studies in Turkey}

Initial studies on India (Indian) in Turkey had been made in parallel with the development process of contemporary Turkish historiography and studies on areas through which Turks have spread throughout history had begun to be carried out in this context, based on the essential working principles of the Turkish Historical Society which had been founded particularly by Mustafa Kemal Atatürk in the early Republic period.

India (Indian) studies in Turkey had primarily two research directions. As also mentioned above, the first of these is the Indology field and this approach rather tended towards the linguistic elements on Indian culture \& literature and determined the scientific scope of the field. Other approaches developed -particularly in historiography - and took as a goal to mention the military, political and human events of Indian history. In this context, again, to carry out research on the Turks' domination period in the region on the axis of holistic Indian history has become the basic approach that has come to the forefront among the main interests of the field.

Studies on India (Indian) Studies in Turkey began with the establishment of the Chair of Indology ${ }^{3}$ in 1936 within the structure of Faculty of Language History and Geography at Ankara University under the guidance of Mustafa Kemal Atatürk. Walter Ruben ${ }^{4}$ (1899-1982), the founder of this department, carried out many studies in the field of Indian literature \& history, by making great contribution in developing Indology field in Turkey, with the identification and evaluation of sections about Turks in Indian sources. Some of these are the studies titled Eski Hint Tarihi (Old Indian History), published in 1944 in Ankara and Budizm Tarihi (History of Buddhism), published in 1947 in Ankara.

In his work titled as Umumi Türk Tarihine Giriş (Introduction to General Turkish History), Zeki Velidi Togan, who brought a new approach to India (Indian) studies the field in Turkey, gave

2 Hanefi Palabıyık, "Hindistan Tarihinde ve Hint Kültüründe Müslüman Türkler", (Muslim Turks in Indian History and Indian Culture), Ekev Akademi Dergisi, 11/33 (2007), 67.

3 Indology is a gigantic-scale field of science, which is addressed within a lot of branches such as language, history, geography, anthropology, archaeology, art history, aesthetics and mythology etc.

4 Born in Hamburg, Walter Ruben, in his young age, took private Sanskrit lessons from Norwegian Indologist Sten Konow. After World War I, he completed his Indology education (study) under the supervision of Hermann Jakobi and H. Levelens in Berlin. He was appointed/assigned to Department Head of Indology at Santiago University in Chile in 1945. He returned to Germany in 1950 and worked as a teacher and administrator at various universities and academies. He died in 1982. 
a place to Turkish states which had been established in the Southern Asian and Indian region of Turkish history. His research titled Hatıralar (Memoirs) proposes different approaches to India and Pakistan which lead to an increase in the interest to these places. The interest aroused by Togan in the field precipated Indian-Turkish history studies in Turkey -the foundations of which were firmly laid on historical and cultural data- and studies in this field continued under the guidance of Abidin İtil ${ }^{5}$ who had was raised following Ruben.

In this context, Abidin İtil carried out a lot of studies in areas of language and literature in the above-mentioned field by maintaining his duty at the chair until 1975. Accordingly, he provided a lot of scientific treatises to be presented in the light of Indian sources with the great efforts by Indologists and historians, such as Kemal Çağdaş. Çağdaş is a leading character in the field of these Indian studies, with many studies on Indian culture \& literature, including the work titled Hint Eski Çă̆ Kültür Tarihine Giriş (Introduction to Cultural History of Indian Ancient Age). ${ }^{6}$ The department of Indology is currently held by Korhan Kaya has many studies on Indian culture-literature.

We would like to state that, to research Turkish history and culture, an institute was established named Türk Kültürünü Araştırma Enstitüsü (Institute of Research on Turkish Culture) ${ }^{7}$ in 1961. One of the most important studies of the institute, Guidebook of Turkish World was published in 1976. It is the first Turkish book to contain systematically information on the geography, history and culture of the Turkish World. The work has the feature of a quite important source for Indian studies in that it gives detailed information on the periods of the Gazhnavid State, Turkish-Indian Empire and its continuation and the Indian-Turkish Empire in India.

While studies on Indian history in Turkey were continuing, translations of studies presented in Western historiography began to be made into Turkish and this issue also contributed to the developing of Turkish-Indian Historiography.

Since our study will mainly bring studies about the Turkish period in India into the forefront, in this context, to present scientific studies on Indian history and culture to readers will be the main aim of our paper.

In Turkey, this field has been elaborated by academicians, historians, authors and researchers such as Zeki Velidi Togan, Y.Hikmet Bayur, Mübarek Galip, M. Fuad Köprülü, Halide Edip Adıvar, Halis Bıyıktay, Emel Esin, İsmail Hikmet Ertaylan, Tevfik Bıyıklığlu, Enver Konukçu, Salim Cöhce, Dursun Ali Akbulut, Erdoğan Merçil, Vahdet Keleşyılmaz, Azmi Özcan, Hanefi Palabıyık, Ahmet Ocak, Mualla Uydu Yücel, Hayrunnisa Alan, Mehmet Tezcan, Ali Fuat Bilkan, S. Haluk Kortel, Erkan Türkmen, Aziz Ahmed, Cemil Kutlutürk,

5 Abidin İtil (1910-1980) was born in Bakü. He graduated from Dil Tarih Coğrafya Fakültesi-DTCF, (Faculty of Language History and Geography), Ankara Üniversitesi in 1940. He became Dr. (PhD) in 1944 and associate professor in 1946. İtil continued his duty at the chair until 1975. He carried out a lot of studies in the fields of language and literature. He was later upgraded to Professorship.

6 Kemal Çağdaş, Hint Eski Çă̆ Kültür Tarihine Girişs (Introduction to the History of Indian Ancient History), (Ankara: Ankara Üniversitesi DTCF Yayınları, 1974).

7 About the Institute, please see http://www.tkaed.org/(Erişim Tarihi: 13.03.2019) 
Saadettin Y. Gömeç, Ali İhsan Yitik, Neslihan Durak, Kutlu Altay Kocaova, Şengül Demirel, H.Hilal Şahin and etc.

Halide Edip Adivar collected her notes of her Indian trip in 1935 in her work titled as Hindistan'a Dair (Inside India). The writer, during this trip, met with important people such as Mahatma Gandhi, Muhammad Ikbal, and Sarojini Naidu etc. and mentioned the progress of independence and modernization of Turkey to Indian people, through her lectures she gave. The book is important one due to the fact that a great writer reflected her neutral observations about an ancient geography. ${ }^{8}$

The work of three volumes, titled as Hindistan Tarihi (History of India) by Yusuf Hikmet Bayur who wrote the first comprehensive study on India could be lited as one of the most important studies on India in our country. The work contains information on Indian history from the ancient ages till 1949. This book, a masterpiece in its field, is significant even today due to the fact that it fills a gap and of the studies which in our country.

In the first volume of Hindistan Tarihi, the period from the ancient ages to the establishment of the State of Gurkanid (1526) was elaborated in detail. ${ }^{9}$ In the work in which many issues on India were studied comprehensively, information about communities who influxed into India during the period before and after the Muslim Turks and also about historical events concerning the states which were established here. In the second volume of Hindistan Tarihi, events developing with the title of Greatness Period the State of Gurkanid were discussed in a detailed way. ${ }^{10}$ In the third volume of Hindistan Tarihi, Bayur gave in detail a place to the period and the experienced history, from Nader Shah Afshar's raid on independence and the Republic (1737-1949) and with this aforementioned literary work by him, he succeeded analytically to present again periods and dynamics of Indian Turkish history. ${ }^{11}$

While Tevfik Bıyıkoğlu implied the aforementioned subject with his book titled as Hint Tarihi (History of Indian) ${ }^{12}$, M. Turhan Tan, who novelized Admiral Süleyman Pasha's campaign to India in XVI ${ }^{\text {th }}$ century, narrated the campaings of Terq-i Yusuf and Terq-i Huseyin Begs in 1543, Piri Reis in 1551, and Seydi Ali Reis in 1553, starting with Süleyman Pasha in 1539, in his work namely Hint Denizinde Türkler (Turks in Indian Sea), published in 2010. ${ }^{13}$

In his work titled as Hindistan Yolu ve Ingilizler (Indian Way and the British), Uğur Akbulut explained why he wanted to write about Indian history, with these statements:

$8 \quad$ Halide Edip Adıvar, Hindistan'a Dair (Inside India), (İstanbul: Can Sanat Yayınları, 2014).

9 Y. Hikmet Bayur, Hindistan Tarihi İlk çağlardan Gurkanlı Devleti'nin Kuruluşuna Kadar I, (History of India, from the First Ages Until the Establishment the State of Gurkanid I), (Ankara: TTK Yayınlar1, 1946).

10 Y. Hikmet Bayur, Hindistan Tarihi Gurkanlı Devleti'nin Büyüklük Devri II, (History of India, the Greatness of the Gurkanid II), (Ankara: TTK Yayınları, 1947).

11 Y.Hikmet Bayur, Hindistan Tarihi Nadir Şah Afşar'ın Akınından Bağımsızlık ve Cumhuriyete Kadar III (1737-1949),(History of India, Independence from the Influence of Nadir Shah Afshar and Republic III), (Ankara: TTK Yayınları, 1987).

12 Tevfik Bıyıklığlu, Hint Tarihi, (History of Indian), (İstanbul: Devlet Matbaası, 1931).

13 Mehmet Turhan Tan, Hint Denizinde Türkler, (Turks in Indian Sea), (İstanbul: Çağrı Yayınları, 2010). 


\begin{abstract}
"India has become a representative of mysterious and charmed world and a symbol of richness with its exotic products throughout the history. It is, first of all, a land \& country of spices. The spices which is a breeze coming from the Heaven, is symbol of statue and power and a gift from kings to kings in Europe. To reach to the source of the valuable goods\&commodity coming from the East, that is India, was a dream of European kings and emperors for hundreds of years. Those who had successed this and reached for the first time to India were the Portugueses. But, the actual domination was established by the British coming India later. India which was a great market and a source of human and raw material for the British added richness to new owners'wealth (richness). For this reason, India was seen as a rare jewellery that is protected by the British carefully and jealously." ${ }_{14}$
\end{abstract}

In this context, the book of Türkkaya Ataöv's titled as Hindistan Siyaset Yazllarl (India Political Writings) is criticial due to the fact that it studies political structure of India in that century as well as gives information about political life and politicians during that period. ${ }^{15}$

Yılmaz Öztuna's study titled as İslam Devletleri, Devletler ve Hanedanlar (Islamic States, States and Dynasties), published in five volumes. The first volume of the study, he mentioned that Muslim domination in Indian geography was provided almost always through Turkish states until the XIX ${ }^{\text {th }}$ century. And during the Muslim-Turkish states almost all of the religious, scientific, architectural, cultural and social activities developed. Second volume is about Turkey, from 1071 and the others are about all world states.

The names, founders, and genelogies of all Turkish states outside of the Turkey-Ottoman area took a place in the chapter Islam Devletleri (Islamic States) of the book. In the second volume in which Turkish are eloborated, the main focus on the Ottoman Empire apart from the periods of the Seljuks and the subsequent Republics. All dynasties and families under the body and frame of the Ottomans were also studied. In the $3^{\text {rd }}, 4^{\text {th }}$ and $5^{\text {th }}$ volumes, other states were mentioned, from the beginning of the written history until today. ${ }^{16}$

İsmail Hikmet Ertaylan, in his research titled as Âdilşâhiler: Hindistan'da Bir Türk-İslam Devleti (Adil-Shahs: A Turkish-Islamic State in India), addressed Adil Shah's biography and the history of Adil-Shahs, a Turkish-Islamic state ruling through the years of 1490-1686 in Bikapur in Indian Peninsula. ${ }^{17}$

Falih Rifk1 Atay collected in 1943 his writings of travel for two months based on his experiences in India in his work named Hind (India). He provided the readers with a top view of this field, elaborating local people, history, religion, the caste system and political cases of the Indian region. Atay's travel to India became a journey; that tale elements have already remained as memories belonging to childhood years in this tale land and instead of this; that

14 Uğur Akbulut, Hindistan Yolu ve Ingilizler, (Indian Way and the British), (Konya: Çizgi Yayınları, 2016), 1-2.

15 Türkkaya Ataöv, Hindistan Siyaset Yazllarl, (Indian Political Writings), (Ankara: Güzeliş Ofset, 2002).

16 Yılmaz Öztuna, Íslam Devletleri Devletler ve Hanedanlar I-V, (Islamic States and Dynasties) I-V, (Ankara: Kültür Bakanlığı Yayınları, 1989).

17 İsmail Hikmet Ertaylan, Âdilşâhiler: Hindistan'da Bir Türk-İslam Devleti, (Adil-Shahs: A Turkish-Islamic State in India), (İstanbul: Sermet Yayınları, 1953). 
was loved with its history, culture and civilization; that had various kinds of the moving charms; and that left very beautiful memories behind it. ${ }^{18}$

The work titled as Timurlular Zamanında Hindistan Türk Imparatorluğu,(Indian Turkish Empire during Timurids) published by Halis B1y1ktay in 1941, deals with the political history of the Baburid State within the period from Babur Shah's ascending the throne of Fergana to the British invasion to India. ${ }^{19}$

In the work titled as Dünya Tarihinde Türklük (Turkishness in World History) ${ }^{20}$, written by Turcologist Laszlo Rasonyi who taught in DTCF (Faculty of Language, History and Geography) at Ankara University, detailed information is given about the periods of the Ghaznavids and Baburid State during these years, there was a board significiant study by Hüseyin Namık Orkun, containing information on the Ghaznavid period in India. This work named Yeryüzünde Türkler (Turks over the World) ${ }^{21}$ consisting of four volumes, includes the Turkish history from pre-Islamic Turkish history to the history of the states and principalities in Anatolia. In the third volume of the work, the Ghaznavid State in India was elaborated.

In 1944, Ömer Rıza Doğrul expalined his purpose in writing the book with these statements in his work named Ekber Bir Türk Dâhisi (Akbar a Great Turkish Genius):

"To the Turkish readers, I am trying to introduce a Turkish genius's personality and his historical value; who ruled and founded a great empire, became one of the greatest conquerors whom the world encountered in terms of conquerorness, and who came to the fore with his administrative capability, his embracement the places which he conquered, his justice and tolerance upon his subject and with his succeeding to sustain the achievement created by him for ages. "22

Born in Tando-Bago in the Sindh region of Pakistan in 1935, M. Yakup Mughul started his research on the subject of Portekiz Tehlikesi Karşısında Osmanlıların Hint Okyanusu Politikası ve Osmanll-Hint Münasebetleri (The Ottoman Policy in Indian Ocean againt Portuguese threat and the Ottoman-Indian Relations) at the the Faculty of Language, History and Geography at Ankara University; after 1972, carried out studies in relation to Turkish History and Language at Faculty of Literature at İstanbul University; and published his study titled as Kanunî Devri: Osmanlıların Hint Okyanusu Politikasl ve Osmanl-Hint Müslümanlarl Münasebetleri: 15171538 (Period of Sultan Süleyman the Magnificent: Ottoman Policy in Indian Ocean and Ottoman-Indian Muslims Relations: 1517-15382323, with Prof. Dr. Halil İnalc1k’s introduction,

18 Faik Rıfkı Atay, Hind, (Indian), (İstanbul: Semih Lütfi Kitabevi, 1944).

19 Halis Bıyıktay, Timurlular Zamanında Hindistan Türk Imparatorluğu, (Indian Turkish Empire during Timurids), (Ankara: TTK Yayınları, 1941).

20 Laszlo Rasonyi, Dünya Tarihinde Türklük, (Turkishness in World History), (Ankara: İdeal Matbaa, 1942).

21 Hüseyin Namık Orkun, Yeryüzünde Türkler, (Turks over the World), (İstanbul: Çınaraltı Yayınları, 1944).

22 Ömer Rıza Doğrul, Ekber Bir Türk Dâhisi, (Ekber a Turkish Genius), (İstanbul: Yüksel Yayınevi, 1944$), 3$.

23 M. Yakub Mughul, Kanunî Devri: Osmanlıların Hint Okyanusu Politikası ve Osmanl-Hint Müslümanlarl Münasebetleri: 1517-1538,(Period of Sultan Suleyman the Magnificent: Ottoman Policy in Indian Ocean and Ottoman-Indian Muslims Relations: 1517-1538), (İstanbul: Fetih Yayınevi, 1974). 
into Indian-Turkish history in 1974. The writer, in his work, elaborated the relations between the Ottoman rulers (sultans) and the Indian Muslims. Halil İnalcık summarized the importance of Indian history for Turks with this statement:

"The Correlation between Anatolian Turkishness and Turkish-Islamic Sultanates, established in India, does not only remain around politic and economic relations, but also-beyond that-, is based on a close cultural kinship/proximity. "24

Asserting that every study about Turkish-Indian relations should elaborate more this period of Turkish history than other all periods, Ayyubi N. Akmal displayed the importance of Turkish-Indian relations by giving that reply to the question "Türkler Hindistan'a elle tutulur ne vermiştir? (What did Turks give to India tangibly?)", in his paper titled "Hindistan Türklere Neler Borçludur? (What Does India Owe to Turks)":

"As Turks were full of a permanent feel of love and sympathy against India, they gave the best of all things that they have in themselves; in fact, effects of Turks on cultural heritage of India cover a wide area. Turks are those who brought a previously-unknown government system and administrative capability institution and who opened the door to intellectual, literary and spiritual activities. ${ }^{25}$

Ayyubi Akmal, in his article titled Hind Kültürü Üzerinde Müslüman Türk Tesirleri (Effects of Muslim-Turks on Indian Culture), pointed out that Arabian conquests in the Sindh region do not carry much value in terms of spreading Islam religion either; and therefore that some Indian historians indicated that Turks are those who brought Islamism to India properly; and added that "Arabs did nothing but sending their soldiers to Sindh and their merchants to Malabar", ${ }^{26}$

Making considerable contributions to the Indian history of the Turks, Salim Cöhce published the journal titled as Hindistan Türk Tarihi Araştırmaları Dergisi (Studies on Indian Turkish History) in 2001 and also included studies of scientists who were struggling for this field. The journal began its publication life as partaking of Zeki Velidi Togan's breakthrough in terms of Turks in India in Turkish historiography in 1964. It was observed that the journal which had been published for three years took a break in its publication life after its 2007 publication. Cöhce did his Doctorate ${ }^{27}$ and gained Associate Professorship and Professorhip upon Indo-Turcia; and put his signature to a lot of studies such as Delhi Türk

24 Mughul, Kanunî Devri: Osmanlıların Hint Okyanusu Politikası ve Osmanlı-Hint Müslümanlarl Münasebetleri, 8.

25 Ayyubi N. Akmal, "What does India owe to Turks?”, (Hindistan Türklere Neler Borçludur?), (Aligarh: Institute of Islamic Studies, Aligarh Muslim University Publiser) (Trans. Nejat Kaymaz), Dil ve Tarih-Coğrafya Fakültesi (DTCF) Tarih Araştırmaları Dergisi, 2/2, (Ankara: Ankara Üniversitesi Yayınları, 1964), 2.

26 Ayyubi N. Akmal, "Effects of Muslim-Turks on Indian Culture”, (Hint Kültürü Üzerinde Müslüman Türk Tesirleri), (İstanbul: İslam Tetkikleri Enstitüsü, 1966), 205-210.

27 Salim Cöhce, Şemsi Melikleri (Shamsi Maliks), (Basılmamış Doktora Tezi, Fırat Üniversitesi, Elazı̆̆g, 1986). 
İmparatorluğu'nda Sultan Şemseddîn İltutmuş'un Kırk Kölesi: Çihilganilerin Kimlikleri ve Oynadıklarl Roller (The Fourty Slaves of Sultan Shams Al-Din Iltutmish in Turkish Sultanate of Delhi: The Chilgani's Identities and Roles They Played) ${ }^{28}$, Hindistan'da Türk Askerî Aristokrasisi (Turkish Military Aristocracy in India) ${ }^{29}$, XIII ve XIV. Yüzyılda Hindistan'da Türk Hakimiyeti (Turkish Domination in India in XIII ${ }^{\text {th }}$ and XIV ${ }^{\text {th }}$ Centuries) ${ }^{30}$, Hindistan' $d a$ Türk Kültürü ve Bugünkü Hint Kültürüne Etkileri (Turkish Culture in India and Its Effects on Indian Culture of Today) ${ }^{31}$, Ilk Çăgda Hindistan'da Türk Varlı̆̆ in the First Age in India) $)^{32}$, Gazneli Mahmud Dönemine Kadar Hindistan'da Türk Varlı̆̆ (Existence of Turks until The Period of Mahmud of Ghazni in India) ${ }^{33}$, Hindistan'da Türk Hakimiyeti'nin Tesisi ve Racalar (Establishment of Turkish Domination and Rajas in India) ${ }^{34}$, Delhi Sultanlığl ve Racalar (The Dehli Sultanate and Rajas) ${ }^{35}$, Gaznelilerin Hindistan Hâkimiyeti (Ghaznavids'domination of India) ${ }^{36}$, Hindistan'da Kurulan Türk Devletleri (Turkish States Founded in India) ${ }^{37}$, Hindistan'da Ilk Türk Hakimiyeti: Kuşanlar ve Akhunlar (The First Domination of Turks in India: Kushans and White Huns) ${ }^{38}$, Hindistan'da Türk Kültürünün Gelişimi ve Hint Kültürüne Tesiri (Development of Turkish Culture in India and Its Effect on Indian Culture) ${ }^{39}$, Büyük Orta Doğu Projesi Bağlamında Hindistan ile Orta Doğu Arasındaki Tarihî Bağlar ve Güncel İlişkiler (Historical Linkages Between India and

28 Salim Cöhce, “Delhi Türk İmparatorluğu'nda Sultan Şemseddîn İltutmuş’un Kırk Kölesi: Çihilganilerin Kimlikleri ve Oynadıkları Roller" (Fourty Slaves of Sultan Shams Al-Din Iltutmish in Turkish Sultanate of Delhi: The Chilgani’s Identities and Roles They Played), Beşinci Milletlearası Türkoloji Kongresi, (İstanbul: 1985).

29 Salim Cöhce, "Hindistan'da Türk Askerî Aristokrasisi” (Turkish Military Aristocracy in India), X. Türk Tarih Kongresi, (Ankara, TTK Yayınları, 1986).

30 Salim Cöhce, “XIII ve XIV. Yüzyılda Hindistan'da Türk Hâkimiyeti” (Turkish Domination in India in XIII ${ }^{\text {th }}$ and XIV ${ }^{\text {th }}$ Centuries) İnönü Üniversitesi Araştırma Projesi, (Malatya, 1996).

31 Salim Cöhce, "Hindistan'da Türk Kültürünün Gelişimi ve Hint Kültürüne Tesiri” (International Development of Turkish Culture in India and its Effect on Indian Culture), VI. Uluslararası Türk Kültürü Kongresi; Türk Kültürünün Dünya Kültürüne Etkileri, (Ankara, 2005).

32 Salim Cöhce, "İlk Çağda Hindistan'da Türk Varlığı” (Turkish Existence in India in the First Age) Hindistan Türk Tarihi Araştırmaları Dergisi, I /I, (Malatya, 2001).

33 Salim Cöhce, “Gazneli Mahmud Dönemine Kadar Hindistan’da Türk Varlığı” (Existence of Turks until The Period of Mahmud of Ghazni in India) Erdem (Aydın Sayılı Özel sayısı) IX/27, Ankara, 1996.

34 Salim Cöhce, "Hindistan'da Türk Hakimiyeti'nin Tesisi ve Racalar” (Establishment of Turkish Domination in India and Rajas) Hindistan Türk Tarihi Araştırmaları Dergisi, (Malatya, 2001).

35 Salim Cöhce, "Delhi Sultanlığı ve Racalar" (The Dehli Sultanate and Rajas), Indian Council of Historical Research International Seminar on Turkish and Indian Studies: An Appraisal, (New Delhi, 2005), 1-18.

36 Salim Cöhce, "Gaznelilerin Hindistan Hâkimiyeti” (The Ghaznavid Empire of India), Türkler içinde, IV, Ed. H.C.Güzel vd. (Ankara: Yeni Türkiye Yayınları, 2002), 522-525.

37 Salim Cöhce, "Hindistan'da Kurulan Türk Devletleri” (Turkish States Established in India), Türkler içinde, VIII, Ed. H.C.Guzel vd. (Ankara: Yeni Türkiye Yayınları, 2002), 689-730.

38 Salim Cöhce, "Hindistan'da İlk Türk Hâkimiyeti: Kuşanlar ve Akhunlar” (Turkish Sovereignty in India: Kushans and White Huns), Türkler içinde, I, Ed. H.C. Güzel vd., (Ankara: Yeni Türkiye Yayınları, 2002), 815-820.

39 Salim Cöhce, "Hindistan'da Türk Kültürünün Gelişimi ve Hint Kültürüne Tesiri” (Development of Turkish Culture in India and its Effect on Indian), Uluslararası 6. Türk Kültür Kongresi; Türk Kültürünün Dünya Kültürüne Etkileri, (Ankara, 2005). 
Middle Asia in the Context of Greater Middle East Initiative and Current Relations) $)^{40}$, Türk Ístiklal Mücadelesi ve Hindistan (Turkish Struggle for Independence and India) ${ }^{41}$, Delhi Türk Sultanlığl'nın Kurucusu Kutbeddin Aybeg'in Hayatı ve Şahsiyeti (Kutbeddin Aybeg's Life and Personality, Founder of Turkish Sultanate of Delhi) ${ }^{42}$, Delhi Türk Sultanlığında Memlûk Sistemi (Mamluk System in Turkish Sultanate of Delhi) ${ }^{43}$ and Delhi Türk Sultanlı $\breve{g} l$ Tarihi (History of Dehli Turkish Sultanate) ${ }^{44}$ etc.

In the journal named as Hindistan Türk Tarihi Araştırmalar (Studies on Indian-Turkish History), published under the guidance of Salim Cöhce in 2001, there are scientific studies of the authors such as Orhan Yazıc1, Ahmet Ocak, Awadh Kishore Narain, Xinru Lin, Osmund Bopearachi etc., as well as articles and writings belonging to those such as Enver Konukçu: Hindistan'daki Türkler (Turks in India) ${ }^{45}$; Neslihan Durak: Hint Sularında Portekiz Hâkimiyetinin Tesiri (Effect of Portoguese domination in Indian Waters); S. Haluk Kortel: Delhi Sultanlı̆̆ında Hükümdarlık Anlayışı (Sense of Sultanate in Turkish Sultanate of Delhi); M. Hanefi Palabıyık: Gaznelilerde İmi Faaliyetler (Scientific Activities in Ghaznavids); Mehmet Tezcan: Kuzey Hindistan Geçitleri (Gateways to North India) and Ali Furkan Bilkan: Sebk-i Hindi (Sabk-i Hindī) etc.

Working as a teaching fellow (faculty member) of the General Turkish History in the Department of History in the Literature Faculty at İstanbul University after his return from Germany to Turkey, as we stated above, Zeki Velidi Togan (1890-1970) published his book titled as Umumi Türk Tarihine Giriş (Introduction to General Turkish History). ${ }^{46}$ This work gives information about the dynasties established in India and important periods of Turkish history, such as the Ghaznavids, Baburid State and Turkish Sultanate of Delhi etc.

40 Salim Cöhce, "Büyük Orta Doğu Projesi Bağlamında Hindistan ile Orta Doğu Arasındaki Tarihî Bağlar ve Güncel İlişkiler" (Historical Linkages Between India and Middle Asia in the Context of Greater Middle East Initiative and Current Relations) Akademik Bakış II / III, (2008).

41 Salim Cöhce, “Türk İstiklal Mücadelesi ve Hindistan” (Turkish Struggle for Independence and India) Tarihte Türk-Hint İlişkileri Sempozyumu Bildirileri (Ankara, TTK Yayınları, 2006), 27-215.

42 Salim Cöhce, "Delhi Türk Sultanlığı'nın Kurucusu Kutbeddin Aybeg'in Hayatı ve Şahsiyeti, 1206-1210" (Kutbeddin Aybeg's Life and Personality, Founder of Turkish Sultanate of Delhi, 1206-1210), Firat Üniversitesi Ilahiyat Fakültesi Dergisi, (Elâzı̆̆, 2010), 5.

43 Salim Cöhce, "Delhi Türk Sultanlığında Memlûk Sistemi” (Mamluk System in Turkish Sultanate of Delhi) Milletlerarası Türkoloji Kongresi, (İstanbul, 1987).

44 Salim Cöhce, Delhi Türk Sultanlı̆̆ Tarihi (History of Dehli Turkish Sultanate), (Malatya: Huzur Yayın Evi, 2001).

45 Enver Konukçu, Kuşan ve Akhunların Tarihi (History of Kushans and White Huns), (Ankara: Sevinç Matbaas1, 1973); Halaci Saltanatı (Khaljis Sultanate), (Yayınlanmamış Doktora tezi, Erzurum, 1977); “Hindistan'da Devlet Kuran Altayl Kabilelerden Hunlar" (Huns Who Founded State in India, from Altaic Tribes), XVI. Milletlerarası Altaistik Kongresi, (Ankara, 1979); "Hindistan'daki Türk Devletleri” (Turkish States in India), Doğuştan Günümüze Büyük Íslam Tarihi, IX, (İstanbul: 1989) 458-460; "Kalaç Sultanı Ala ed-din Muhammed Şah ve Onun Hind Siyaseti" (Sultan Ala al-Din Muhammad Shah of Khaljis and His Indian Policy), VIII. Türk Tarih Kongresi Tebliğleri, (1984), 793-798; "Dehli Kalaç Sultanlığının Kuruluşu” (Establishment of Khaljis Sultanate of Dehli) IX. Türk Tarih Kongresi Tebliğleri, (1988), 587-593; "Hind Kaynaklarında Hunlara Dair Bazı Kayıtlar" (Some Records for Huns in Indian Sources), Atatürk Üniversitesi Edebiyat Fakültesi Dergisi, (Erzurum, 1983), 5.

46 Zeki Velidi Togan, Umumi Türk Tarihine Giriş (Introduction to General Turkish History) (İstanbul: İsmail Akgün Matbaas1, 1946). 
In this repect, Zeki Velidi Togan's study titled as Hatıralar (Memoirs) is significiant for the field. Memoirs in which impressions concerning his Indian and Pakistan visits were presented contain valuable data. In this context, the work, in which there are also meetings by him with Indian Prime Minister Jawaharlal Nehru (1889-1964) and Pakistan President İskender Mirza (1899-1969) in Togan's visiting, brings new images to researchers for the field.

Putting his signature to important studies on Indian Turkish History, Enver Konukçu stated in his article:

"Zeki Velidi Togan had gone to India for a congress. He presented his study on Khaljis' domination in Bengal as the proceeedings. When he returned Istanbul, he stated that IndiaTurcica studies should be begun, by telling his impressons of the Indian trip. Togan, who saw the current studies were not enough, in fact, even though there were those who carried out studies in this field, had dwelt upon the Timurid's Afghanistan and Pakistan campaigns for weeks, while giving courses on Timurid and his State during the term of 1964-1965 with the scope of Asian history and also showed some sources and books, in the meanwhile. All these efforts were to complete the previous studies in general nature and to guide as far as possible those who would study Turkish History which developed in India. (...). When I went to visit my teacher after a while, he said to me 'Indo-Turcica field belongs to you. Accordingly, please begin to study'. And I accepted this as a command. I have had considerable studies on Turks in India. (...) Thus, Indo-Turcia, that is Turkish-Indian Studies, also took shape." ${ }^{\text {47 }}$

These statements by Konukçu both present how he began the current field and constituted the framework of studies which have been envisioned for the relevant field.

Enver Konukçu received the $\mathrm{PhD}$ titled with his thesis Kuşan ve Akhunların Tarihi (History of the Kushans and White Huns), he later worked at Karachi University in the Islamic Republic of Pakistan as a Teaching Fellow, began Indian History studies at the Department of Islamic History and later worked as the head of Department of History at Atatürk Universiy. He also has many more articles, studies and works, such as Hindistan'daki Türk Devletleri (Turkish States in India $)^{48}$ Babürlüler, Hindistan'daki Temürlüler (Baburids: Timurids in India) ${ }^{49}$, Babürlüler (Baburids) ${ }^{50}$, Ekber (Akbar) ${ }^{51}$, XII-XVI. Yüzyıllarda Hindistan'da Türk Kurucular ve Hanedanlar (Turkish Founders and Dynasties in XII-XVI ${ }^{\text {th }}$ centuries in India). ${ }^{52}$

Islam Mimarisi (Islamic Architecture) by S. Kemal Yetkin is very important for IndianIslam Period. This book was first published in 1954 and then in 1959. The current one is the

47 Enver Konukçu, "Presentation”, Hindistan Türk Tarihi Araştırmaları Dergisi, I/I (Research Studies of IndiaTurkish History, I/ I) (Malatya, 2001), 1-2.

48 Enver Konukçu, "Hindistan'daki Türk Devletleri” (Turkish States in India), Büyük İslam Tarihi, I/XV, Ed. H. Dursun Yıldız, (İstanbul: Çă̆ Yayınları, 1989), 63-71.

49 Enver Konukçu, "Babürlüler, Hindistan’daki Temürlüler” (Baburids: Timurids in India), Türkler içinde, VIII, (Ankara: Yeni Türkiye Yayınları, 1991), 1321-1345.

50 Enver Konukçu, "Babürlüler” (Baburids) Diyanet İslam Ansiklopedisi, IV, (İstanbul, 1990), $397-405$.

51 Enver Konukçu, "Ekber” (Akbar), Diyanet İslam Ansiklopedisi, X, (İstanbul, 1994), 542-544.

52 Enver Konukçu, “XII-XVI. Yüzyıllarda Hindistan'da Türk Kurucular ve Hanedanlar” (Turkish Founders and Dynasties in XII-XVI ${ }^{\text {th }}$ centuries in India) Erdem, IX/27, (Ankara, 1994), 1177-1183. 
third edition. In every new edition, the author examined new research. This book contains detailed information about Islamic architecture in India. ${ }^{53}$

The work titled as Gazneliler Devleti Tarihi (History of Ghaznavid State) by Erdoğan Merçil gives information about Ghaznavids that were one of the Medieval Turkish states. In addition, states and emirates around it during the establishment period of the Ghaznavid State were also discussed. This work consists of articles which were written about the Ghaznavids. In the work, there is advice (Pendname) on state governance, given from Sebuk Tigin, who is the founder of the Ghaznavid Dynasty, to his son, Mahmud. Moreover, Indians in the army of the Ghaznavid State were also mentioned in this study. This book is an important study in that it presents information about organization, zoning (public works) and cultural activities as well as the political history of the Ghaznavids. ${ }^{54}$

Erdoğan Merçil published his book titled Afganistan ve Hindistan'da Bir Türk Devleti Gazneliler (Siyaset, Teşkilat, Kültür),(Ghaznavids: A Turkish State in Afghanistan and IndiaPolicy, Organization, Culture) after his work named History of Ghaznavid State. The writer in this study, presented new information on organization, zoning (public works) and cultural activities of the Ghaznavid State as well as its political history based on the sources of the period as a detailed study on the period of the Ghaznavids by also collecting articles on the subject of Indian-Turkish History. ${ }^{55}$

Müslüman Türk Devletleri (Muslim-Turkish States), written by Merçil, gave quiteenlightening information on the Turkish states ruled in India. In the book, there is explanatory information on the establishment of the Ghaznavids and Baburid State and rulers (Sultans) who reigned during this period. ${ }^{56}$

Also, the study by Aziz Ahmed, titled as Siyasi Tarihi ve Müesseseleriyle Delhi Türk Imparatorluğu (Turkish Sultanate of Delhi with Its Political History and Institutions), sheds light particularly on the political aspects of the Turkish state which was founded in Delhi by Kutbeddin Aybeg who was one of commanders of the Muslim Ghurid State. ${ }^{57}$

Vahdet Keleşy1lmaz, in the research titled as Teşkilâtı Mahsûsa'nın Hindistan Misyonu (1914-1918)(Indian Mission of the Special Organization: Teskilat-l Mahsusa), tried to enlighten and evaluate relations between India and Turkey and developments based on these documents of Teskilat-1 Mahsusa (Special Organization) in particular. The writer, further, presented the historical origin of relations between Indian Muslims and Turkey to the readers. ${ }^{58}$

53 S. Kemal Yetkin, İslam Mimarisi (Islamic Architecture), (Ankara: Ankara Üniversitesi Yayınları, 1963).

54 Erdoğan Merçil, Gazneliler Devleti Tarihi (History of Ghaznavids State), (Ankara: TTK Yayınları, 1989).

55 Erdoğan Merçil, Ghaznavids Afganistan ve Hindistan'da Bir Türk Devleti Gazneliler -Siyaset, Teşkilat, Kültür(Ghaznavids, a Turkish State in Afghanistan and India), (İstanbul: Bilge Kültür Sanat Yayınları, 2014).

56 Erdoğan Merçil, Müslüman Türk Devletleri (History of Muslim Turkish States) (Ankara: TTK Yayınları, 2006).

57 Aziz Ahmed, Siyasi Tarihi ve Müesseseleriyle Delhi Türk Imparatorluğu (Turkish Sultanate of Delhi with Its Political History and Institutions) (İstanbul: Kervan Yayınları, 1949).

58 Vahdet Keleşyılmaz, Teşkilâtı Mahsûsa'nın Hindistan Misyonu (1914-1918)(Indian Mission of Teskilat-ı Mahsusa -Special Organization- 1914-1948), (Ankara: Atatürk Araştırma Merkezi Yayınları, 1999). 
Azmi Özcan, in his book namely Pan-İslamizm, Osmanlı Devleti, Hindistan Müslümanlarl ve Ingiltere (Pan-Islamism, Ottoman Empire, Indian Muslims and England) (1877-1924), mentioned that the relationship between Indian Muslims and Turks began in the beginning of the $\mathrm{XI}^{\text {th }}$ century and with the Ottomans in the middle of the $\mathrm{XV}^{\text {th }}$ century, evolved as from 1870 s. $^{59}$ The writer emphasized that Indian Muslims took action for the Ottomans and the continuity of the Ottoman Empire and made self-sacrifice until the abolition of the Caliphate in 1924. Furthermore, in his book, in which Özcan stated that India was a British colony as well as historical, religious and cultural linkages between the two countries (Turkey\&Ottomans and India) and this situation also added a political feature to relations between them, therefore Britain and British policy became involved. He examined relations between Indian Muslims and Ottomans from 1877-1878 Russo-Turkish (Ottoman) War (The 93War) to 1924 when the Caliphate was abolished in Turkey and elaborated the existence of historians who evaluated Osmanl-Hindistan Münasebetleri (Indian-Ottoman Relations) in the framework of general "Pan-Islamism" due to the importance of the mentioned period defined as "Panislamism". ${ }^{60}$

By carrying out a distinctive study with her book titled as Hindistan'a Kuzeyden Yaplan Seferler (Military Campaigns to India from North), Neslihan Durak addresses in detail the campaigns in India, executed by land, particularly over gateways in the Northwest. Durak, in her book, pointed out that India was one of the regions had been exposed to invasions consistently due to its facilities and that the thought of confiscating its richnesses by reaching this country turned into a high "ideal" during some periods. She also emphasized the reason why a balanced society had not been constituted throughout history of India vis-a-vis invasions. On the other hand, the writer mentioned these following crucial points:

"Turks reaching India from North tried to hold on the region, with their culturel and political existence. But their efforts could not leave a lasting impression beyond being a temporary movement until the $X I^{\mathrm{th}}$ century. However, Turkish military campaigns, executed in India as from this century, was effective at first-degree until the beginning of the $X X^{\text {th }}$ century and would had important consequences. " 61

This book by the author who stated that there were campaigns which were executed in India, by land, particularly over the gateways in the Northwest, has the feature of becoming a guide to the reader(s) and the researcher(s) in consequence of the fact that it was the first considerable study that has been carried out in this direction.

By organizing a symposium in 2002, titled as Turkish-Indian Relations in the History

59 Azmi Özcan, Pan-İslamizm, Osmanlı Devleti, Hindistan Müslümanlarl ve İngiltere (1877-1924),(Pan-Islamism, Ottoman Empire, Indian Muslims and England 1877-1924), (Ankara: İSAM Yayınlar1, 1997).

60 Azmi Özcan, “Osmanl1-Hindistan Münasebetleri” (Ottoman-Indian Relations İslam), Íslam Ansiklopedisi, XVIII, (İstanbul, 1998), 81-85.

61 Neslihan Durak, Hindistan'a Kuzeyden Yapılan Seferler (Military Campaigns to India from North) (Ankara: ASAM Yayınları, 2000). 
Turkish Historical Society (Türk Tarih Kurumu, TTK) made contribution in studies carried out in relating to Indian history in our country. In this symposium, Türk-Hint Ilişskileri (TurkishIndian Relations) were addressed with proceedings which were presented by international scientists as well as communiqués titled Dursun Ali Akbulut: İlkçăgda Soğdia ve Baktria ile Hindistan Illişkileri (Indian Relations with Sogdiana and Bactria in the First Age) ${ }^{62}$; Mehmet Tezcan: Kuşanlar, Akhunlar ve Eftalitler (Kushans, White Huns and Ephthalites) ${ }^{63}$; Erdoğan Merçil: Gazneliler ve Hindistan (Ghaznavids and India) ${ }^{64}$; Enver Konukçu: Hindistan 'daki Türk Devletleri (Turkish States in India) ${ }^{65}$; A. R. Khan: Matrix of Autobiography: Some Observations on Babur's Memories ${ }^{66}$; SN. R. Farooqi. Mughal India And The Ottoman Empire: A Study in Early Modern Diplomacy And Diplomatic Procedure ${ }^{67}$; Salim Cöhce: Türk Istiklal Mücadelesi ve Hindistan (Turkish Struggle for Independence and India); ${ }^{68}$; Esin Kâhya: İlkçağda Hindistan-Türk Düşüncesi Arasındaki İlişkiler (Relations between Turkish-Indian Thought in the First Age) ${ }^{69}$; M. Hanefi Palabıyı: Hint Dinleri ve Islam (Indian Religions and Islam) ${ }^{70}$; Fikret Türkmen: Hint-Türk Folklor Etkileşimi (Indian-Turkish Folklore Interaction) ${ }^{71}$; Ali Fuat Bilkan: Hindistan Kütüphanelerindeki Türkçe El Yazmaları ve Hindistan'da Türkçe (Turkish Manuscripts at Indian Libraries and Turkish in India). ${ }^{72}$

The second Tarihte Türk-Hint Illişkileri Sempozyumu (Turkish-Indian Relations in History) was held by TTK in 2007. In the symposium, the proceedings which were presented by the

62 Dursun Ali Akbulut, "İlkçağda Soğdia ve Baktria ile Hindistan İlişkileri” (Indian Relations with Sogdiana and Bactria in the First Age) Tarihte Türk-Hint İlişkileri Sempozyumu Bildirileri (31 October- 1 November 2002), (Ankara: TTK Yayınları, 2006), 1-9.

63 Mehmet Tezcan, "Kuşanlar, Akhunlar ve Eftalitler" (Kushans, White Huns and Ephthalites), Tarihte Türk-Hint İlişkileri Sempozyumu Bildirileri (31 October- 1 November 2002), (Ankara: TTK Yayınları, 2006), 9-57.

64 Erdoğan Merçil, "Gazneliler ve Hindistan" (Ghaznavids and India) Tarihte Türk-Hint İlişkileri Sempozyumu Bildirileri (31 October-1 November 2002), (Ankara: TTK Yayınları, 2006), 57-63.

65 Enver Konukçu, "Hindistan'daki Türk Devletleri” (Turkish States in India) Tarihte Türk-Hint Illişkileri Sempozyumu Bildirileri (31 October- 1 November 2002), (Ankara: TTK Yayınları, 2006), 67-73.

66 A. R. Khan, "Matrix of Autobiography: Some Obversations on Babur's Memories", "Turkish States in India", Tarihte Türk-Hint İlişkileri Sempozyumu Bildirileri(25-28 June 2002), (Ankara: TTK Yayınları, 2006), 73-85.

67 SN. R. Farooqi, "Mughal India And The Ottoman Empire: A Study in Early Modern Diplomacy and Diplomatic Procedure", Tarihte Türk-Hint İlişkileri Sempozyumu Bildirileri (25-28 June 2002), (Ankara: TTK Yayınları, 2006), 85-127.

68 Salim Cöhce, “Türk İstiklal Mücadelesi ve Hindistan” (Turkish Struggle for Independence and India), TurkishTarihte Türk-Hint Illişkileri Sempozyumu Bildirileri (31 October-1 November 2002), (Ankara: TTK Yayınlar1, 2006), 127-217.

69 Esin Kâhya, "İlkçağda Hindistan-Türk Düşüncesi Arasındaki İlişkiler” (Relations between Turkish-Indian Thought in the First Age) Tarihte Türk-Hint İlişkileri Sempozyumu Bildirileri (31 Ekim-1 Kasım 2002) (Ankara: TTK Yayınları, 2006), 257-275.

70 M. Hanefi Palabıyı, "Hint Dinleri ve İslam" (Indian Religions and Islam), Tarihte Türk-Hint İlişkileri Sempozyumu Bildirileri (31 Ekim-1 Kasım 2002), (Ankara: TTK Yayınları, 2006), 275-339.

71 Fikret Türkmen, "Hint-Türk Folklor Etkileşimi”" (Indian-Turkish Folklore Interaction), Tarihte Türk-Hint İlişkileri Sempozyumu Bildirileri (31 Ekim-1 Kasım 2002), (Ankara: TTK Yayınları, 2006), 339-351.

72 Ali Fuat Bilkan, "Hindistan Kütüphanelerindeki Türkçe El Yazmaları ve Hindistan'da Türkçe” (Turkish Manuscripts at Indian Libraries and Turkish in India, Tarihte Türk-Hint Illişkileri Sempozyumu Bildirileri (31 Ekim-1 Kasım 2002) (Ankara: TTK Yayınları, 2006), 351-36. 
foreign scientists took a place as well as communiques titled Halil Akınc1: Turkish-Indian Symposium ${ }^{73}$; Aswini K. Mohapatra: Bridge to Anatolia Indo-Turkish Relations in Different Phases of History ${ }^{74}$; Salim Cöhce: Kalaç Sultanlı̆̆l (Sultanate of Khaljis) ${ }^{75}$; M. Hanefi Palabıyık: Hindistan Tarihinde Gazneli Türk Hakimiyeti (Ghaznavid Turkish Domination in Indian History) ${ }^{76}$; Suat Vural: Hindistan 'da Ingiliz Hakimiyetinin Kurulmast (Establishment of British Domination in India) ${ }^{77}$; Neslihan Durak: Hindistan'da Saka, Kuşan ve Akhunlar (ScythiansSakas, Kushans, White Huns in India) ${ }^{78}$; Enver Konukçu: Hindistan'daki Kalaçların Başkentleri: Lakhnauti, Delhi, Dhar ve Mândû (Capital Cities of Khaljis in India: Lakhnauti, Delhi, Dhar and Mându) ${ }^{79}$; Azmi Ozcan: Osmanlı Coğrafyasında Hintli Bir Şeyh: Muttaki el-Hindî (An Indian Sheikh in Ottoman Geography, Muttaqi al-Hindi). ${ }^{80}$

We encountered the study, written by A. Fuat Bilkan-Şadi Aydın, titled as Sebk-i Hindi ve Türk Edebiyatında Hint Tarzı (Sebk-i Hindī and Indian Sytle in Turkish Literature) a new Persian poetry movement that got conceptualized in the Indian Palace. It would be the most accurate method to address to the origins of this poem which breaks off the current one and thus to examine it within the historical process. The fact that there has been no detailed study except for a few articles in this field indicates the usefulness of such a study for Sebk-i Hindi can't be discussed. This part of the book related to our study is that the Persian language spread into India from the Baburid State and it was used as an official and literary language. The auother, with this study, reminds the reader(s) and also researcher(s) of the existence of Persian sources with regard to Turkish domination of the period. ${ }^{81}$

A. Fuat Bilkan, in his study titled as Sultan' in Dini (The Religion of the Sultan), examined how politics instrumentalized religion based on determination with regard to interesting adventures in his life, rules, beliefs and livings (experiences) of Akbar Shah's, who was one of

73 Halil Akınc1, "Turkish-Indian Symposium", Tarihte Türk-Hint İlişkileri Sempozyumu Bildirileri (25-28 June 2007) (Ankara: TTK Yayınları, 2008), 19-23.

74 Aswini K. Mohapatra, "Bridge to Anatolia Indo-Turkish Relations in Different Phases of History", TurkishIndian Relations Symposium Proceedings in History, (25-28 June 2007) (Ankara: TTK Yayınları, 2008), 23-31.

75 Salim Cöhce, "Kalaç Sultanlığı" (Sultanate of Khaljis), Tarihte Türk-Hint İlişkileri Sempozyumu Bildirileri (25-28 June 2007), (Ankara: TTK Yayınları, 2008), 77-91.

76 M. Hanefi Palabıyı, "Hindistan Tarihinde Gazneli Türk Hakimiyeti" (Ghaznavid Turkish Domination in Indian History) Tarihte Türk-Hint İlişkileri Sempozyumu Bildirileri (25-28 June 2007) (Ankara: TTK Yayınları, 2008), 91-129.

77 Suat Vural, "Hindistan'da İngiliz Hakimiyetinin Kurulması" (Establishment of British Domination in India), Tarihte Türk-Hint Illişkileri Sempozyumu Bildirileri (25-28 June 2007) (Ankara: TTK Yayınları, 2008), 129-139.

78 Neslihan Durak, "Hindistan'da Saka, Kuşan ve Akhunlar" (Scythians-Sakas, Kushans, White Huns in India), Tarihte Türk-Hint İlişkileri Sempozyumu Bildirileri, (25-28 June 2007) (Ankara: TTK Yayınları, 2008), 139-145.

79 Enver Konukçu, "Hindistan'daki Kalaçların Başkentleri: Lakhnauti, Delhi, Dhar and Mândû" (Capital Cities of Khaljis in India: Lakhnauti, Delhi, Dhar and Mândû), Tarihte Türk-Hint İlişkileri Sempozyumu Bildirileri (25-28 June 2007) (Ankara: TTK Yayınları, 2008),145-173.

80 Azmi Özcan, "Osmanlı Coğrafyasında Hintli Bir Şeyh: Muttaki el-Hindî" (An Indian Sheikh in Ottoman Geography, Muttaqi al-Hindi), Tarihte Türk-Hint İlişkileri Sempozyumu Bildirileri (25-28 June 2007) (Ankara: TTK Yayınları, 2008), 173-183.

81 Ali Fuat Bilkan, Sebk-i Hindi ve Türk Edebiyatında Hint Tarzl (Sabk-i Hindī and Indian Sytle in Turkish Literature) (İstanbul: 3F Yayınları, 2007). 
the Baburid States's rulers. Bbased on (with reference to) studies belonging to the researchers who made significiant studies in this field, together with primary sources of the period such as Ekbername (Akbar-Nama), Ain-i Ekberi (Ain-i Akbari) and Müntehabu't-Tevârih (Muntakhab al-Tawarikh), it elaborated the past of long political history in terms of political development experienced in modern times. ${ }^{82}$

The study of S. Haluk Kortel's named as Delhi Türk Sultanliğında Teşkilat (Organization in Turkish Sultanate of Delhi 1206-1414) could be mentioned as one of the important works which were carried out on the administrative mentality and the functioning of Turkish Sultanate of Delhi. The work was evaluated by Enver Konukçu as such: In the work, the author addressed in detail the administrative organization and institutions (in other words, the sultanate/rulership institution and domination mentality, palace, government, army, judicial organizations and land administration) through the years of 1206-1414. The Turkish Sultanate of Delhi (1206-1526), a Turkish-Islamic state founded in India, was under the administration of Turkish dynasties (Qutbis, Shamsis, Balabans, Khaljis, Tughlaqs) were examined in detail. Although it was rich in sources of the studies carried out about this period of our history in Turkey were still uncommon in number. ${ }^{83}$

In the work titled as Sultan Raziye (Sultana Razia), written by Erkan Türkmen, the writer told Razia's life story, who was the first Turkish and Muslim woman that became ruler (sultana) in India in the beginning of XIII ${ }^{\text {th }}$ century and he made social-political structure during the period of Turkish Sultanate of Delhi. ${ }^{84}$

Sultana Razia, also known as Razia Sultana or Razia Begum, (1236-1240) was the daughter of Sultan Şemseddin İltutmuş (Shams Al-Din Iltutmish), who was born of his wife (Terken/ Türkan Hatun) whom he favoured and respected much and deemed her worthy of staying at Kökş-ü Firûzi (Kushk-i Firozi-Royal Palace) as the first wife of the sultan (baş-kadın) in the harem. And Razia was prepared for the future with a great care without getting married off contrary to traditions. ${ }^{85}$

The importance of the existence of Turks in India is summarized with the sentences: "Aceh, Indonesia, Malaysia, Singapore, Japan, South Korea and India... these seven countries of South Asia and the Far East still carry the traces of a lost civilization, the Ottoman. For these countries, the Ottoman was not an expression of a state and Turks not of a nationality. Rather, these countries glorified the Ottoman and Turks as representative of a belief system and a civilization attitude which is still alive in their memories and which they idealized by refining to some extent", Ekrem Saltık, with his work titled as Güney Asya ve Uzak Doğu'da Osmanlı

82 Bilkan, Sultan 'in Dini (The Religion of the Sultan's) (İstanbul: Timaş Yayınları, 2015).

83 S. Haluk Kortel, Delhi Türk Sultanlı̆̆ında Teşkilat 1206-1414 (Organization in Turkish Sultanate of Delhi 1206-1414) (Ankara: TTK Yayınları, 2006).

84 Erkan Türkmen, Sultan Raziye (Sultan Razia) (İstanbul: Nüve Kültür Merkezi Yayınları, 2007).

85 Aziz Ahmed, Siyasi Tarihi ve Müesseseleriyle Delhi Türk Imparatorluğu (The Turkish Empire in Delhi with its Political History and Institutions) (İstanbul: Tercüman 1001 Eser Yayınları, 1981), 203. 
İzleri (The Ottoman Traces in South Asia and Far East), gave information about Turkish states in Indian subcontinent and set up its home (land) in that geography. ${ }^{86}$

The study, written by Egemen Çağrı Mızrak and titled M.Ö. 7. Yüzyıldan M.S. 6. Yüzyılın Ortalarına Kadar Batı Türkistan ve Kuzey Hindistan'daki Bozkır Kavimleri (The Steppe Peoples of Western Turkistan and Northern India from the $7^{\text {th }}$ Century BC to the Mid-6th Century). ${ }^{87}$ shows strong evidence that these steppe nomads might be of Altayli and especially of Turkish origin as a result of an analysis of genealogy, socio-cultural and physical anthropological structures and genetic markers.

Some studies of Cemil Kutlutürk on Indian religion and Islam such as titled Hint Düşüncesinde Islam Algist ${ }^{88}$ (Perception of Islam in Indian Thought), contributes to the field.

In addition to these works, the following articles are the ones that can be regarded on this subject.

Refik Turan and Fatma Ahsen Turan wrote an article titled as Hindistan'a Yaplan Bir Araştırma Gezisi ve Balabanlar (A Research Trip to India and the Balabans) ${ }^{89}$ which has elaborated research into the history of Turkish culture. The aim of the study was to investigate the various aspects of Ottoman-Turkish geography and to find out if there is a connection between the Turkish community and Balaban Sultanate.

Zeki Velidi Togan wrote an article on Ephthalites titled as "Eftalit Devletini Teşkil Eden Kabilelere Dair" (On the tribes forming the state of Ephthalites). ${ }^{90}$

Köprülüzade Mehmet Fuad (known as Mehmet Fuat Köprülü), in his article titled as Gazneliler Devrinde Türk Şiiri (Turkish Poetry during the period of Ghaznavids) ${ }^{91}$ studied different points of views on the literary history of Indian Turkish history.

The article of Sadık Armutlu's titled as Gazneliler ve Selçuklular Döneminde Edebi Gelenek (Literary Tradition during the Period of Ghznavids and Seljuks) ${ }^{92}$ examines of Indian Turkish history, in terms of literature.

The article of Abdulhamit Birışık’s titled as Hint Alt-Kıtasında İslâm Araştırmalarının Dünü

86 Ekrem Saltık, Güney Asya ve Uzak Doğu'da Osmanll İzleri (Ottoman Traces in South Asia and Far East) (İstanbul: Nesil Basım Yayın Gıda Ticaret ve Sanayi A.Ş, 2011).

87 Egemen Çăgrı Mızrak, M.Ö. 7. Yüzylldan M.S. 6. Yüzyllın Ortalarına Kadar Batı Türkistan ve Kuzey Hindistan'daki Bozkir Kavimleri (The Steppe Peoples of Western Turkistan and Northern India from the $7^{\text {th }}$ Century BC to the Mid- $6^{\text {th }}$ Century) (İstanbul: Ötüken Neşriyat, 2017).

88 Cemil Kutlutürk, Hint Düşüncesinde İslam Algısı (Perception of Islam in Indian Thought) (İstanbul: Dergâh Yayınları, 2019).

89 Refik Turan-Fatma Ahsen Turan, "Hindistan'a Yapılan Bir Araştırma Gezisi ve Balabanlar" (A Research Trip to India and the Balaban), Türk Kültürü ve Hacı Bektaş Veli Araştırma Dergisi, 35, (Ankara: Gazi Üniversitesi Yayınları, 2005), 113-144.

90 Zeki Velidi Togan, "Eftalit Devletini Teşkil Eden Kabilelere Dair", Atatürk Üniversitesi Fen Edebiyat Fakültesi Araşttrma Dergisi, (Erzurum, 1985), XIII/1, 58-63.

91 Mehmet Fuat Köprülü, "Gazneliler Devrinde Türk Şiiri” (Turkish Poetry during the period of Ghaznavids), Türk Dili ve Edebiyatı Hakkinda Araştırmaları Dergisi, (İstanbul, 1934), 2-32.

92 Sadık Armutlu, "Gazneliler ve Selçuklular Döneminde Edebi Gelenek" (Literary Tradition During the Ghaznavids and Seljuk Period), Türkler Ansiklopedisi, V, (2002), 872-879. 
Bugünü: Kurumlar, İlmî Faaliyetler, Şahıslar, Eserler (Past and Today of Islamic Studies: Institutions, Scientific Activities, Characters, Works) ${ }^{93}$ presents and elaborated Islamic studies in India.

Arslan Terzioğlu's article titled as El-Bîrûnî (973-1051), Great Turkish Scholar of the Ghaznavid Period ${ }^{94}$ examines El-Biruni, who is a great scholar of the period, presents a view on the cultural life of the Ghaznavids period.

H. Ahmed Özdemir's article titled as Ekber Şah 'ın Din Modeli ve Imam-ı Rabbani (Akbar Shah's Religion Model and Imam Rabbani) ${ }^{95}$ discusses the religious policy of the Baburid State period.

Another article of H. Hilal Şahin's named as Osmanll-Hint İlişkilerine Genel Bir Bakış $X V$-XVIII.yy (A General Outlook on Ottoman-Indian Relations, XV-XVIII ${ }^{\text {th }}$ century) ${ }^{96}$ evaluates Ottoman-Baburid relations.

H. Hilal Şahin's article titled Babürlü Sultanı Gülbeden Begüm (Baburid Sultana: Gulbeden Begum $)^{97}$, deals historically with Gulbeden Begum who is a Baburid princess. In this study, there is information about the life of Gülbeden Begüm, who is the daughter of Babur Shah who is the the founder of the Turkish state (Baburids) established in India. In this book, Gülbeden wrote her memoirs in her life from a woman's point of view.

Again in H. Hilal Şahin's article titled as Sosyal Tarih Açısından Bir Hatıratın Muhteva Analizi, “Gülbeden Begüm'ün Hümâyûnnâmesi (Context Analysis of a Memoirs in Terms of Social History, Gulbeden Begum's Humayun-Nama), presented as the proceedings at the International Prof. Dr. Halil Inalc1k History and Historiography Symposium (Uluslararası Prof. Dr. Halil İnalcık Tarih ve Tarihçilik Sempozyumu) which was held by TTK, the determination of concepts and elements for social historiography in the Humayun-Nama were discussed and the relevant concepts were analysed in terms of historical sociology. This study, is significant in terms of the viewpoint of historical sociology and at the same time the first social analysis study for the field as a contribution to the literature in this context.

Şahin's article titled as Bir Ingiliz Türk Savaşında Hintli Askerler: Kût'ül-Amâre'de Sosyal Bir Dram (Indian Soldiers in a War of British-Turkish: A Social Tradegy in Kut-al Amara) ${ }^{98}$ is another study in the field.

93 Abdulhamit Birışık, "Hint Alt-Kıtasında İslâm Araştırmalarının Dünü Bugünü: Kurumlar, İlmî Faaliyetler, Şahıslar, Eserler" (Past and today of Islamic studies: Institutions, Scientific Activities, Characters, Works) Dîvân: Disiplinlerarası Çalışmalar/17 (2004), 1-62.

94 Arslan Terzioğlu, “Gazneliler Devrinin Büyük Türk Alimi Al-Bîrûnî (973-1051)” (Great Turkish Scholar of Ghaznavid Period, Al-Bırunî-973-1051) Haseki Tıp Bülteni Tıp Bülteni, 12, Ayrı Baskı) (1974), 3.

95 Ahmed Özdemir, “Ekber Şah'ın Din Modeli ve İmam-1 Rabbani” (Akbar Shah's Religion Model and Imam Rabbani), Altınoluk Dergisi 188 (2001), 21.

96 H. Hilal Şahin, "Osmanlı-Hint İlişkilerine Genel Bir Bakış XV-XVIII. Yüzyıl”" (A General Outlook on OttomanIndian Relations-XV-XVIII ${ }^{\text {th }}$ century).” Akademik Tarih ve Düşünce Dergisi 2/6, (2015), 59-77.

97 H. Hilal Şahin, "Babürlü Sultanı Gülbeden Begüm” (Baburid Sultana: Gulbadan Begum), Akademik Tarih ve Düşünce Dergisi, 3/8, (2016), 1-23.

98 H. Hilal Şahin, "Bir İngiliz Türk Savaşında Hintli Askerler: Kût'ül-Amâre'de Sosyal Bir Dram” (Indian Soldiers in a War of British-Turkish: A Social Tradegy in Kut-al Amara), Akademik Tarih ve Düşünce Dergisi 4/13, (2017), 1-23. 
The study of Şahin's titled as Hintli Bir Alimin Tarihte Yöntembilim Çalışması: Ziyâeddin Berenî 'nin Târîh-î Fî̀ûşâhî̀ Eserinin Modern Tarih Yazıcılı̆̆l Açısından Değeri (An Indian Scholar's Methodology Study in History: Value of The Work of Tarikh-i Firoz Shahi by Ziaud Din Barani in Terms of Modern Historiography) ${ }^{99}$, is published in the proceeding at History and Historiography Symposium (Tarih ve Tarihçilik Sempozyumu) held by TTK 2018. It examined Tarikh-i Firoz Shahi of Ziaud Din Barani who was one of the statesmen of the period of the Sultanate of Delhi, one of the periods of Indian Turkish history, in terms of modern historiography.

The article of Şengül Demirel's titled as Hindistan'da Türk İzleri (Turkish Traces in India) ${ }^{100}$, provides general information about the Turkish presence in India.

The article of Cihan Oruç's titled as Şah Cihan Döneminde Babürlü-Safevi Diplomatik İlişkileri (Baburid-Safavid Diplomatic Relations during The Period of Shah Jahan) ${ }^{101}$ examines the diplomatic relations of the Baburid State period.

İlber Ortaylı wrote an article titled as 19. Asırdan Zamanımıza Hindistan Üzerine Türk Seyhatnameleri, (Turkish Travels on India from the 19th Century to Our Times). ${ }^{102}$ As we know, travelogues are certainly important sources of cultural and social history and historical geography.

The paper (article), titled Türk Kültürünün Hindistan Uygarliğına Etkisi (Influence of Turkish culture on the Indian Civilization) and written by B. Bakuleva, R. Avakova \& J. Abeldayev ${ }^{103}$ discusses the factors of influence of Turkic culture on Indian civilization. Turkic-Islamic influence is reflected in Indian architecture, literature, art and in other spheres of culture. The borrowed elements are the result of Turkic-Indian cultural-linguistic interrelation. Turkic loanwords in Hindi are the representative of historical-cultural connection for a few centuries. The author concluded that the exchange of lexical units between different structures of Hindi and Turkic languages was based on geographical, cultural, historical and social factors.

The article of Cemil Kutlutürk titled as "Müslüman Türklerin Hint Dili ve Edebiyatına Katklsı" (Contribution of Muslim Turks to Indian Language and Literature) ${ }^{104}$ provides general information about the Muslim-Turks presence in India and contributions Indian culture.

99 H. Hilal Şahin, "Hintli bir Alimin Tarihte Yöntembilim Çalıșması: Ziyâeddin Berenînin Târîh-î Fîrûzşâhî Eserinin Modern Tarih Yazıcılığı Açısından Değeri” (An Indian Scholar's Methodology Study in History: Value of The Work of Tarikh-i Firoz Shahi by Ziaud Din Barani in Terms of Modern Historiography), XVIII. Türk Tarih Kongresi, (Ankara, 2018).

100 Şengül Demirel, “Hindistan'da Türk İzleri” (Turkish Traces in India), ICANAS 38, International Congress of Asian and North African Studies, (Ankara: Atatürk Kültür, Dil ve Tarih Yüksek Kurumu Yayınları, 2009$), 95$.

101 Cihan Oruç, "Şah Cihan Döneminde Babürlü-Safevi Diplomatik İlişkileri”" (Baburid-Safavid Diplomatic Relations during Shah Jahan), Vakanüvis-Uluslararası Tarih Araştırmaları Dergisi, $2 / 2$ (2017), 191-205.

102 İlber Ortaylı, “19. Asırdan Zamanımıza Hindistan Üzerine Türk Seyahatnameleri”, (Turkish Travels Books on India from the 19th Century to Our Times), Ankara Üniversitesi Siyasal Bilgiler Fakültesi Dergisi, 3/47, (Ankara, 1992), 271-277.

103 B. Bakuleva, R. Avakova \& J. Abeldayev “Türk Kültürünün Hindistan Uygarlığına Etkisi” (The Effect of Turkish Culture on Indian Civilization) Türk Dünyası İncelemeleri Dergisi, XII/1, (İzmir, 2012), 441-454.

104 Cemil Kutlutürk, "Müslüman Türklerin Hint Dili ve Edebiyatına Katkısı", (Contribution of Muslim Turks to Indian Language and Literature), BİLIG Türk Dünyast Sosyal Bilimler Dergisi, 87 (2018), 33-58. 


\subsection{Thesis on India (Indian) Studies in Turkey}

In this context, we can examine another type of study on India (Indian) studies in turkey which are Master's and Doctoral thesis:

\subsubsection{Postgraduate (Master's) Thesis}

Concerning our subject, when we have scanned the National Thesis Database of the Council of Higher Education, we encounter Post Graduate (Master's) Thesis that we put in order below:

Post-graduate (master's) study of Cemile Akça Ataç's dated back 1998 and titled Risaleler Savaşı (1807-1809): Doğu Hindistan Şirketi’nin Dinsel Hoşgörü Politikasına Karşı Misyonerlerin Tepkisi ile Ortaya Çıan Önemli Bir Kriz (War of Pamphlets -1807-1809: An Important Crisis with the Response of Missionaries Against the Religious Tolerance Policy of the East India Company) ${ }^{105}$, addresses (War of Pamphlets) through the years 1807 to 1809. These events are an important crisis that, due to restrictions upon free movement of missionaries in India, conflict existing between missionaries and East India Company became apparent and it is one of important developments of the period.

Again, concerning the field, Hafiz Aamir Ali's post graduate study, dated 2017 and titled Hindistan'da son Türk Sultan II. Bahadır Şah Zafer (Bahadır Şah) ve 1857 Bağımsızlık Savaşı (Bahadur Shah Zafar II, The Last Turkish Sultan in India, and 1857 Independence War), ${ }^{106}$ addressed Bahadur Shah Zafar who was the last padishah (sultan) of the Baburid State and an important figure of India in the fields of history, literature, culture and politics of the $19^{\text {th }}$ century. The most important aspect of this thesis is that it indicated Muslim domination which began with Mahmud of Ghazni in India and which again ended with Bahadur Shah Zafar, a Turkish commander.

Post graduate study of İsa Eryılmaz's, dated 2011 and titled Hindistan'da Racputlar (Rajputs in India) ${ }^{107}$, addresses Rajputs who came into the area again with Hun-Turks who headed towards India in history. In the study, it is dwelt upon that name for one of their tribes is Huna while Rajputs are being mentioned, is criticial for the field.

In this respect, Mustafa Keskin's post graduage study, dated 2005, titled Ingilizlerin Hindistan'ı Sömürgeleştirme Hareketleri (The British's Colonization Movements of India) ${ }^{108}$, examines British colonialism in India between $17^{\text {th }}$ century and $19^{\text {th }}$ century.

105 Cemile Akça Ataç, Risaleler Savaşı (1807-1809): Doğu Hindistan Şirketi'nin Dinsel Hoşgörü Politikasına Karşı Misyonerlerin Tepkisi ile Ortaya Çıkan Önemli bir Kriz (War of Epistles 1807-1809: An Important Crisis with the Response of Missionaries Against the Religious Tolerance Policy of the East India Company), (Basılmamıs Yüksek Lisans tezi, İhsan Doğramacı Bilkent Üniversitesi, Sosyal Bilimler Enstitüsü, İstanbul, 1998).

106 Hafiz Aamir Ali, Hindistan'da Son Türk Sultanı II. Bahadır Şah Zafer ve 1857 Bağımsızllk Savassl (Bahadur Shah Zafar II, The Last Turkish Sultan in India, and 1857 Independence War), (Basılmamı̧̧ Yüksek Lisans tezi, Necmettin Erbakan Üniversitesi, Sosyal Bilimler Enstitüsü, Konya, 2017).

107 İsa Eryılmaz, Hindistan'da Racputlar (Rajputs in India),(Basılmamış Yüksek Lisans tezi, Gaziosmanpaşa Üniversitesi, Sosyal Bilimler Enstitüsü, Tokat, 2011).

108 Mustafa Keskin, Ingilizlerin Hindistan'ı Sömürgeleştirme Hareketleri (The British's Colonization Movements of India), (Basılmamış Yüksek Lisans tezi, Hacettepe Üniversitesi, Sosyal Bilimler Enstitüsü, Ankara, 2005). 
Still, concerning the field, Muharrem Tan's Post Graduate study, carried out in 1999, titled Hindistan'ın Bölünmesi ve Hint Müslümanlarl (1858-1947) (Division of India and Indian Muslims: 1858-1947) ${ }^{109}$, examines situation of Indian Muslim in parallel to the division (secession) of India in $19^{\text {th }}$ century.

We could mention other thesis namely, Yasin Karakuş, XIII. ve XIV. yüzyılda Hindistan'da Türk Hâkimiyeti (The sovereignty of Turks in India in the XIII ${ }^{\mathrm{rd}}$ and XIV ${ }^{\mathrm{th}}$ Centuries) ${ }^{110}$

H. Hilal Çağlayan's master thesis in 2005 and titled as Ekber Şah Döneminde Hindistan (1542-1605) (India during the Period of Akbar Shah-1542-1605) ${ }^{111}$, contributes to the field.

Melahat Hande Turgut, Gupta Imparatorluğu: Hindistan'ın Altın Çă̆ (M.S. 4-6.yy) (Gupta Empire: The Golden Age of India 4-6 ${ }^{\text {th }}$ Centuries A.D. $)^{112}$

Timur, Mujiburahman, Gazneli Devletinden Babürler Devletine Kadar Bölgede Kurulan Hükümdarlıklar (1206-1526) (The Indian Dynasties Established from the Ghaznawi's until the Baburian State) ${ }^{113}$

\subsubsection{Doctoral (PhD) Thesis}

Concerning our subject, when we have examined the National Thesis Database of the Council of Higher Education, here are these Doctoral Thesis:

Mehmet Alpargu's doctoral study (thesis), dated 1983 and titled Diğer Kaynaklarla Göre Karşılaştırma Yolu ile Babürname'nin Türk Devlet Teşkilatı Bakımından Değerlendirilmesi (Evaluation of Babürname in Terms of Turkish State Organization by Comparing with Other Source) ${ }^{114}$, makes an analysis of the Babur memoirs from the point of view of Turkish state organization.

The doctoral study (thesis) of Gülseren Halıcı Abay's dated 1995 and titled as Hindistan 'da Kalıcı Türk Izleri (Permanent Turkish Traces in India) ${ }^{115}$, contains detailed information on the roles of the Turks in forming Indian culture. In the work, the period of Baburid State is examined in every aspect.

109 Muharrem Tan, Hindistan ’’n Bölünmesi ve Hint Müslümanlarl: 1858-1947 (Division of India and Indian Muslims: 1858-1947), (Basılmamış Yüksek Lisans tezi, Marmara Üniversitesi Orta Doğu ve İslam Ülkeleri Enstitüsü, İstanbul, 1999).

110 Yasin Karakuş, XIII. ve XIV. yüzyllda Hindistan'da Türk Hâkimiyeti (The sovereignty of Turks in India in the $X I I$. and $X I V^{\text {th }}$ Centuries) (Trakya Üniversitesi, Sosyal Bilimler Enstitüsü, Edirne, 2015).

111 H. Hilal Çağlayan, Ekber Şah Döneminde Hindistan (1542-1605) (India During Akbar Shah-1542-1605), (Basılmamış Yüksek Lisans tezi Ankara Üniversitesi, Sosyal Bilimler Enstirtüsü, Ankara, 2005).

112 Melahat Hande Turgut, Gupta Imparatorluğu: Hindistan'ın Altın Çă̆ı MS 4-6 yy) (Gupta Empire: The Golden Age of India $4-6^{\text {th }}$ centuries AD), (Basılmamış Yüksek Lisans tezi, Ankara Üniversitesi Sosyal Bilimler Enstitüsü, Ankara, 2009).

113 Timur Mujiburahman "Gazneli Devletinden Babürler Devletine Kadar Bölgede Kurulan Hükümdarlıklar" (1206-1526), (The Indian Dynasties Established from the Ghaznawi’s Until The Baburian State 1206-1526), (Basılmamış Yüksek Lisans tezi, Selçuk Üniversitesi Sosyal Bilimler Enstitüsü, Konya, 2012).

114 Mehmet Alpargu, Diğer Kaynaklarla Göre Karşılaştırma Yolu ile Babürname’nin Türk Devlet Teşkilatı Bakımından Değerlendirilmesi (Evaluation of Babürname in Terms of Turkish State Organization by Comparing with Other Source), (Basılmamış Doktora tezi, Ankara Üniversitesi, Sosyal Bilimler Enstitüsü, Ankara, 1983).

115 Gülseren Halıcı Abay, Hindistan'da Kalıcı Türk İzleri (Permanent Turkish Traces in India) (Basılmamış Doktora tezi, Ankara Üniversitesi, Sosyal Bilimler Enstitüsü, Ankara, 1995). 
The doctoral thesis of Mukadder Güneri's titled as Babür'ün Sosyal ve Kültürel Hizmetleri (Babur Shah's Social and Cultural Services) ${ }^{116}$, contains information about the period of Baburid State although general information on Turkestan and India are the main addressed subjects.

The doctoral thesis of Seyfullah Palalı's in 2012 and titled as Delhi'deki Babürlü Türbeleri (Baburid Tombs in Delhi), dwells upon the position and the importance of Delhi tombs (shrines) in developing Baburid architecture. It gives explanation about the positions of the tombs in Islamic and the Turkish tomb architecture vis-a-vis their interactions with other tomb structures, and the similarities and differences between them.

The doctoral thesis Özlem Nurben Öztoksoy's published in 2007 and titled as 16-18. Yüzyllarda Osmanlı-Hint-Baburlu Kumaş Sanatlarının Etkileşimleri (Interactions of Cloth Arts of OttomanIndian-Baburid of 16-18 $8^{\text {th }}$ Centuries) ${ }^{117}$, could be evaluated as a secular study for the field.

The doctoral thesis, H. Hilal Şahin's in 2014 and titled as Ekber Şah ve Dini Reformu (Akbar Shah and His Religious Reform) ${ }^{118}$ is another study that contributes in the concerning field. The study which addresses Akbar Shah and his religious policies, which affected the Baburid period with his distinctive approach. The thesis mainly elaborated religious and cultural life of the period.

Last but not least, we could mention the doctoral thesis of Canan Kuş's titled as XVI. Yüzyllda Ticarî Alanda Osmanl-Hindistan İlişkileri (Commercial Area Relationships Between the Ottoman and India at $16^{\text {th }}$ Century). ${ }^{119}$ and Mesut Şen, Gazi Zahirüddin Muhammed Babur, Baburname (Kabil ve Hindistan Bölümleri) (Gazi Zahiruddin Muhammad Babur, Baburnamah (Chapters of Kabul and India). ${ }^{120}$

\subsection{Works Translated into Turkish in Indian Studies}

Ghazi Zahiruddin Muhammed Babur's ${ }^{121}$ work in the memoir genre, printed regularly in a

116 Mukadder Güneri, Babür'ün Sosyal ve Kültürel Hizmetleri (Babur Shah's Social and Cultural Services) (Basılmamış Doktora tezi, Ankara Üniversitesi, Sosyal Bilimler Enstitüsü, Ankara, 2000).

117 Özlem Nurben Öztoksoy, 16-18. Yüzyıllarda Osmanlı-Hint-Baburlu Kumaş Sanatlarının Etkileşimi (Interactions of Cloths Arts of Ottoman-Indian-Baburid of 16-18 ${ }^{\text {th }}$ Centuries) (Basılmamıs Doktora tezi, İstanbul Üniversitesi, Sosyal Bilimler Enstitüsü, İstanbul, 2007).

118 H. Hilal Şahin, Ekber Şah ve Dini Reformu (Ekber Shah and Religious Reform), (Basılmamış Doktora tezi, Ankara Üniversitesi, Sosyal Bilimler Enstitüsü, Ankara, 2014).

119 Canan Kuş, XVI. Yüzyılda Ticarî Alanda Osmanlı-Hindistan İlişsileri (Commercial Area Relationships Between Ottoman and India at 16th Century), (Basılmamış Doktora tezi, Fırat Üniversitesi, Sosyal Bilimler Enstitüsü, Elâzı̆̆, 2012).

120 Mesut Şen, Gazi Zahirüddin Muhammed Babur, Baburname (Kabil ve Hindistan Bölümleri), (Basılmamış Doktora tezi, Marmara Üniversitesi, Türkiyat Araştırmaları Enstitüsü, İstanbul, 1993).

121 Fernand Grenard, in his work, uses these statements about Babur (1483-1530) "Although Babur had a first-agree role in Asian history, he is relatively less known for. However his product was longer lasting, he was less known than Temur, his ancestor. Nothing left from that lightning conqueror after one hundred years. Babur founded Indian (Baburids State) Empire. Four centuries intervening have just strenghtened and developed this empire. Although Indian Dynasty of Timurids, whose founder is Babur, lost its actual (de facto) power after British's Indian campaign in 1765 , it continued nominally to rule until the great rising (revolution) in 1857, but died completely in 1862.” Fernand Grenard, Babür, (Trans. Orhan Yüksel), (İstanbul: Millî Eğitim Basımevi, 1971), 3. 
lot of languages, was published with title of Vekâyî: Bâbür'ün Hâtırâtı (Memoirs of Babur) ${ }^{122}$ in two volumes and translated into today's Turkish language by Reşit Rahmeti Arat. ${ }^{123}$

While starting in the memoirs form, this work, written in the autobiography genre, is seen to have taken the form of a diary when its next sections have been examined, due to the fact that experiences were written from day to day and sometimes without a long intervening time period. The work gives such a great attention and importance to detailed information that it has had an utterly different impact on subjects such as geography, history, botany, zoology and folkore etc. For example, the section in which Sultan Husain Baykara was mentioned as a historical figure; the first four chapters of the work were of a Transoxia history of the Timurids period; and sections in which poets and famous characters were mentioned in this biographical memoir (tezkere) genre.

Upon these striking aspects, when we have added that the example of the autobiography genre is scarcely encountered during the old literature period in which it was written and that it was also written by a ruler's own pencil, it is seen that the work has a priceless importance.

In the Baburnama, which is an original source for the history of Middle Asia, Afghan and India of the period when it was written, Zahiruddin Muhammad Babur makes the readers feel like (instead of a ruler) a naturalist chat-lover, by his modesty, who does not hesitate to deal with even ordinary aspects of life and who narrates well what he experienced and saw. This gives the work more attractive atmosphere.

Written by Mirza Muhammad Haydar Duğlat ${ }^{124}$ who is not only as a history writer (historiographer) but also as one of the historical figures, He is cousin of Babur Shah (Babür Şah) is the founder of Baburid-Turkish State in India and who is leader and beg of Duglat tribes in Mongolia; the work titled Tarih-i Reşidî (Tarikh-i Rashidi) is a history of events which took place in Middle Asia, Uyghuristan, Mughalistan, Tibet and today's Pakistan in $16^{\text {th }}$ century. This book which is one of the main sources for Turkish history and has become a source and reference for studies on the history of Middle Asia and Tibet and Indian-Turkish history until today it was translated into English by Denison Ross and annotated by N. Elias translated into Turkish with about a 100-year delay and published by Selenge Publications, Tarih-i Reşhidi is a reference study that those who are interested in Turkish history and want to learn about the story of what we left behind (in the past) and events which were written as one-to-one observations, would not be able to pass up. ${ }^{125}$

122 Wrote a wide preface to Turkish translation of Babur's Memoirs, Y. Hikmet Bayur discusses various names given to Babur's Memoirs and consistency degrees of these.

123 Gazi Zahirüddin Muhammed Bâbür, Vekâŷ̂: Bâbür 'ün Hâtırâtı, (Trans. Reşit Rahmeti Arat), (Ankara: Türk Tarih Kurumu 'TTK' Yayınları, 1987), 8-11. Babur's work in authobiography genre are called various names: among the most common names, there are the ones such as Babürname, Waqa'i/Vekâyî (Events), Waqiat-i Babari/Vâki'ât-i-Baburi (Babur's Events) and Tuzuk-i-Baburi.

124 Mirza Muhammad Haydar Duğlat was born in Oretobe around Tashkent in 1499, died in Kashmir country of India of today in 1551. He left two works to World culture despite of his life that passed through politically and socially. These are: Cihannûma and Tarih-i Reşhidi.

125 Mirza Muhammad Haydar Duğlat, Tarih-i Reşhidi (Tarikh-i Rashidi) (Trans. Osman Karatay), (İstanbul: Selenge Yayınları, 2006). 
Published in 1944, Hümâyûnnâme (Humayun-Nama) of Gülbeden Begüm was translated by Abdürrab Yelgar and then Yusuf Hikmet Bayur's preface and historical abstract were annotated to the work. Hümâyunnâme is a significant work in terms of the socio-economic history of the period. It also gives information about Babur's last years, members of the dynasty and events taking place at the palace and harem life. Written by a member of the dynasty belonging to Baburid State which constitutes a very important circle of Turkish history in a different geography, Hümayûnnâme is an important historical data source. Therefore, there are two important reasons that make Hümayûnnâme significant for the readers: ${ }^{126}$

The first reason is that Hümayûnnâme is written by a woman. Even though she was a member of a dynasty, it is very important for us that the period was addressed and told by her with elegancy and politeness. Even from this point of view, it could be considered that it presents an intellectual development in Turkish history without making gender discrimination, in terms of the ideas of a woman, beyond being simply a historical data source. Gülbeden Begüm who presented the period, in which she lived, in a fluent language and and intellectual knowledge, proves with the work that how masterful she used Turkish and Persian.

Secondly reason which makes Hümayûnnâme valuable in terms of cultural history. In fact, written from a broad point of view and with the eye of an enlightened woman, the memoirs with symbols will also shed light on the social life of that period, illustrating socio-economic and cultural experiences of the period to us.

One of the important studies on Indian-Turkish history that could be referred is Mübarek Galip's study titled as Hindistan'da Türkler (Turks in India). The original name of this study is Hindistan'daki Türk Hükümdarları (Turkish Rulers in India) with the sub-heading Timurilerin Hindistan'a dâhil Oldukları Zamana Kadar ve 603-962 Senelerinde Delhi'de İcra-i Saltanat Eden Hükümdarlar "Rulers Who Reigned Sultanate in Delhi until Timurids Got Involved in India and between the Years of 603-962”. Saadettin Yağmur Gömeç, who was one of the faculty members of the Department History at Faculty of Language, History and Geography (DTCF) at Ankara University, translated this work into Turkey Turkish in 1990. But, during that period it was out of print and made available to the readers again with the name of Hindistan'da Türkler (Turks in India) by providing new information. In the study, it is mentioned Turkish history from the first Islamic conquests in India definitively occupied by the British in 1858. ${ }^{127}$

Yuluğ Tekin Kurat gives information on India during the period of the Turkish Sultanate of Delhi in India, with the study titled as Hindistan'daki Türk Tesiri Illk Dönem-1206 (Turkish Impact in India, The First Phase-1206), writtten by S.A. H. Haqqi, into Turkish. ${ }^{28}$

126 Gülbeden, Hümâyûnnâme, (Humayun-Nama) (Trans. Abdürrab Yelgar), (Ankara: TTK Yayınları, 1944).

127 Mübarek Galip, Hindistan'da Türkler (Turks in India), (Trans. Saadettin Y. Gömeç), (Ankara: Berikan Yayınevi, 2013).

128 S. A. H. Haqqi, Hindistan'daki Türk Tesiri Ilk Dönem-1206 (Turkish Impact in India, The First Phase-1206), (Trans. Y. Tekin Kurat), (Ankara: Orta Doğu Teknik Üniversitesi ‘ODTÜ’Yayınevi, 1984). 
In the work titled as Hindistan'da İslam Kültürü Çalışmaları (Studies in Islamic Culture in the Indian Environment) by Aziz Ahmed, the development of Islamic culture in India considered as a response to tensions arising out of its tenacious persistence for survival in a completely foreign environment and to the compromises it made from time to time in the overwhelmingly non-Muslim environment of India as well a regional formulation of the universal Islamic culture. The writer therefore addressed the subject in two main parts: in the first part, he examined it in relation to the Muslim World in general; in the second part, in relation to Hindu India. The work consists of two chapters: The First Chapter, Muslim India in Relation to the Islamic World (710-1947); The Second Chapter, Muslim India in Relation to Hindu India (710-1830) were elaborated broadly. ${ }^{129}$

Published by the Turkish Historical Society (TTK), translated by Nevres Kadim Abd-al Razzaq b. Abdullah, and prepared for publication by Fahri Unan the memoirs of Baburid Emperor Cihangir (Jahangir) Shah, Târih-i Selim Shah (Tarikh-i Salim Shahi: Remembrance of Cihangir Shah) also contributes to the Indian history of Turks. The work is the translated into Turkish of today from the copy that was translated into Ottoman Turkish of the period by Nevres Kadim Abd-al Razzaq b. Abdullah, at Sultan Mustafa III's request at the beginning of the XVI ${ }^{\text {th }}$ century, of Persian version also known as Cihangir-name or Tüzük-i-Jahangiri written by Nur-ud-Din Selim Shah who is famous for Cihangir Shah, the fourth of the emperors of the Baburid State which emerged with the retreat to India of the descendants of the Timurid Empire after it had dissolved at the beginning of the XVI ${ }^{\text {th }}$ century and later with the establishment of a strong state here. The work continues with Cihangir Jahangir Shah's memories. ${ }^{130}$

Barthold, who stated "You can't write history of any nations without Turks", one of the important writers of his period, contributed to the Turkish world with his studies and published many significiant studies particularly on Turkish history. He gave lectures on Turkish history at Istanbul University and these lectures were published with the title, Lectures on the History of Turkic People of Central Asia, as a collection in a volume. In addition, in his work titled as Moğol Ístilasına Kadar Türkistan (Turkestan Down to Mongol Invasion), Barthold mentioned Ghaznevids, as one of the Muslim-Turkish states which were established in India. The work was published by Hakk1 Dursun Y1lmaz in 1990 in Turkish language of today. ${ }^{131}$

Tabaqât-i Nâsirî by Minhâj-i Sirâj al Jûzjâni, who is a XIII ${ }^{\text {th }}$ century-historian, has an exceptional and important place for studies of medieval history due to the information it gives about the Mongol invasion. Minhâj-i Sirâj al Jûzjâni is an eye-witness to the invasion since he was present at some cities which faced the Mongol invasion. ${ }^{132} \mathrm{He}$ composed his study by

129 Aziz Ahmed, Hindistan'da Íslam Kültürü Çalışmalarl (Studies in Islamic Culture in the Indian Environment), (Trans. Latif Boyac1) (İstanbul: İnsan Yayınları, 1995).

130 Nûrü'd-Din Cihangir Şah, Nevres-i Kadîm, Târih-i Selim Shah (Trans. Fahri Unan) (Ankara: TTK Yayınları, 2013).

131 V.Vladimiroviç Barthold, Moğol İstilasına Kadar Türkistan (Turkestan Down to Mongol Invasion), Ed. Hakk1 Dursun Yıldız, (Ankara, TTK Yayınları, 1990).

132 Minhâc-1 Sirâc el Cûzcâni, Tabakât-i Nâsirî (Trans. Mustafa Uyar) (İstanbul: Ötüken Yayınları, 2016). 
recording events based on information from the trusted people. M. F. Köprülü emphasizes he significance of this work with the statement "...for a historian who deals with the Mongolian period, to say Tabakât- $i$ Nâsirî is an important source in the first-degree is not wrong at all...”. The study was created by adding the needed notes after XXIII ${ }^{\text {rd }}$ sheet, in which the Mongolian invasion was narrated and translated by Mustafa Uyar. This book written by Minhâj-i Sirâj al Jûzjâni in his declining years has a distinguished place in Persian literature of the XIII ${ }^{\text {th }}$ century thanks to its good style and description power.

Herman Kulke's work, named Hindistan Tarihi (History of India), written by D. Rothermund and brought in Turkish with translation by Mufit Gunay, is also a considerable work in this respect. ${ }^{133}$

In the 1940s, in his book titled as Büyük Türk Hindistan Kapılarında: Kanunî Sultan Süleyman Devrinde Amiral Hadım Süleyman Paşa'nın Hind Seferi (Great Turk at the Gate of India: Admiral Hadim Suleiman Pasha's Military Advance to India during the Period of Suleiman the Magnificent), published in Selami Sertoğlu Yayınevi, of Herbert Melzig, one of professors at İstanbul University, gave summaries of some Portuguese documents, in addition toaddition, he presented the Indian campaign together with its stages of historical development and in detail. ${ }^{134}$

Türkkaya Ataöv's book titled as Keşmir, Hindistan ve Komşuları (Kashmir, India and Neighbours) was published in September 2014. The study of which the first edition was out of print in a short time was translated from English to Turkish. This book was based on firsthand sources, including the libraries of New Delhi, Srinagar and New York and consists of 18 chapters. The study which discusses the boundaries, historical geography and political events of the region in the first chapters, examines also the subjects namely national structuring, terror, violence in the region dealing with peace struggles in the region. ${ }^{135}$

\section{Determinations and Suggestions}

\subsection{Determinations}

The studies on the field in Turkey began with the establishment of the Department of Indology in 1936 under the guidance of Mustafa Kemal Atatürk, during the early Republican period. The scientific framework of these studies which would be carried out in this direction was determined by Ruben and it made progress. Determinations on studies about Indian history in Turkey are in line with the direction of these studies. The main problematic of these studies came into prominence in linguistic and historical issues. The fact that the region had a

133 Herman Kulke, D.Rothermund, Hindistan Tarihi (History of India) (Trans. Müfit Gunay), (Ankara: İmge Yayınları, 2001).

134 Herbert Melzig, Büyük Türk Hindistan Kapılarında: Kanunî Sultan Süleyman Devrinde Amiral Hadım Süleyman Paşa'nın Hind Seferi (Great Turkish Gate of the Indian Salt Sultan Suleiman the Magnificent in the era of Suleyman Pasha's Hind Expedition) (İstanbul: Selami Sertoğlu Yayınları, 1943).

135 Türkkaya Ataöv, Keşmir, Hindistan ve Komşuları (Kashmir, India and Neighbours) (Trans. Funda Keskin AtaElif Ağaoğlu) (Ankara: TTK Yayınları, 2014). 
particularly multi-lingual and -cultural structure made it preferable to carry out studies based on the dominant languages, and studies for the field essentially concentrated around the axis of both linguistic and historical studies from the very beginning. As a matter of the fact, the first research chair was established under the name of Indology. This name has already come into prominence as the first step of studies which will make linguistic and historical approach.

Studies also continued as Indian history- and Indian Turkish history- axis based on Indian sources and it was provided that historical periods and development for Turks were partly addressed in Indian historical sources. In the studies, generally, India was elaborated and gained importance as a historical geography of field studies, and Indian studies in general and studies about Indian Turkish history in particular proceeded in parallel with each other. The first generation-Indian studies were addressed with an analytical approach of historical, geographical and linguistic fields; second-generation field studies rather dealt with present the historicalness of Indian-Turkish history. Drawing attention to the cultural approaches of the issue of conveyance of Turkish culture to the region as a consequence of that fact that Turks came to India, studies were presented, rather based on relation of Turkish culture with Indian culture.

This situation, in studies, brought about approaches to the study of the main cultural assets of Turks who founded their own states in India region and state models of Turkish states such as the Kushans, White Huns and Ghaznavids etc. on the axis of (based on) migratory routes of ancient Turks who came to India from North; and ways to what extent they preserved their own culture by the region in which they were founded; were tried to be addressed.

Based on these studies, it was also seen how state organization by Turks in India prepare the historical ground for Turkish states founded later in the region. Various thesis were carried out at the Higher education in different periods in Turkey.

\subsection{Suggestions}

Studies on Indian and Indian-Turkish history are still continuing. In this respect, we suggest that interdisciplinary collaboration and epistemological approaches are necessary for the field. Minimizing problematic issues of the field studies since the very beginning, first of all, will be overcome through harmony which will arise from interdisciplinary collaboration. Particularly, the fact that; a considerable part of the studies which present basic data for studies in terms of researching and interpreting (commenting) on Indian Turkish history was in the Persian language; and that Persian is used as cultural language in Turkish states ruled in the region; increase the importance of Persian in field studies. In this respect, it is an essential issue that research centers and related departments for India should be in cooperation with Persian language departments. The fact that field sources and some chronicles have not been completely reflected on today's studies, yet, justifies our suggestions on this issue. For example, while it is an inevitable situation that Tarih-i Firûz Şahi (Tarikh-i Firoz Shahi) would be much more benefitted that is a Persian work and that presents significant data for Turkish Sultanate of Delhi period, this work could not 
be taken into consideration because of the language problem. This leads to important studies in the field to be translated into Turkish since all relevant into Turkish by forming commissions. In this respect, the Turkish Historical Society must be translated publish and translation significant field works such as Humayun-Nama by Gülbeden Begüm.

Considering Asian studies and works in European and American literature, it could be understood that difficult it is for these field studies to conduct with in the Department of Indology and including different perspectives. It is neccessary that different disciplines should be in cooperation with each other. In this context, the departments of Indology and history departments in close cooperation with departments such as Turkish Language and Literature, Sociology, Psychology and Science of Religion etc. in Indian history studies which will make studies richer.

The second-generation Indian history studies and today's field studies articulated to Indian Turkish history studies and deepened in terms of social and cultural issues will provide neccessary for points for historical, social and cultural connection to be revealed clearer.

Conducting ethnological studies in the field of the historicity of the beginning of Turkish culture to hold on the region in parallel for Turks to establish states in India and of its being in relation with local cultures will no doubt present important data to historical studies.

Studies carried out in other languages for Indian studies translated into Turkish will broaden the perspective of the studies as well as adding a different dimension to them.

Another issue on this subject-matter that researchers who would conduct studies for the field should be academically raised. Raising better equipped historians and scholars who will work in this context will make no doubt great contributdion to field studies.

New thesis, projects and scientific studies on this issue will contribute to the field.

\section{Conclusion}

The studies in Indian history began during the early republic period in Turkey. Mustafa Kemal Atatürk initiated studies about Indian history as an inheritance to the next generations. In this context, he also provided that Indology Department included the historiography field in Turkey with the multilateral perspective, which bought Indian studies in Turkey. Starting out with the Indology department in Indian studies indicates the importance of the languagehistory partnership in the current field.

The first-generation Indian history studies in Turkey presented the basic approaches of the field and with their serious studies, they brought in scientific framework for Indian Turkish history studies which will gain acceleration in this lane.

In this respect, the existence of Turks in India which went back many years was proven by many studies on this issue. Bringing a different life in India for a long period of Turks time left a socio-cultural heritage in this geography. It would not be wrong to say that Turkey brought in Indian sub-continent was a considerable amount, from Eyyubi N. Akmal's point of view, who said: "As Turks were full of with a permanent feel of love and sympathy for India, they 
gave the best of all things that they have in themselves."

This study presenting certain studies for the field aims to make a contribution in Indian Turkish history studies with the subjects of presenting certain studies for the field in Turkey.

Following after Zeki Velidi Togan who made the breakthrough of Turks in India in Turkish historiography; such historians as Fuad Köprülü; Yusuf Hikmet Bayur, with his study named Indian History, who presented the source to a lot of researchers and historians, passed the torch to scientists such as Salim Cöhce, Enver Konukçu, Erdoğan Merçil by completing duly his duty (part) in this field. New academicians began to make names for themselves thanks to the power of the current literature in this field. Since mentioning all articles and scientific studies on this subject would exceed the volume of this paper, which will focus on the main subject of releated literature.

With this current study, mentioning and elaborating different figures, academicians and aouthers who studied on Indian History in Turkey, we made some observations and evaluations for studies on Indian Turkish history and culture form the past until today.

Our suggestions for the field are foloows: While we expect that Indian studies and published works should increase continue, we must state the requirement that regional studies including conceptual framework in particular should be made in an interdisciplinary context. Both the progress and development of studies based on implementation of different methods and scientific approaches for field studies; will no doubt contribute to the field.

We hope that, be a significant step that (this social and cultural history study) under the guidance of many different studies which have been presented until now. In this context, in terms of historicity of social and cultural images. It would also be possible that these images will provide access to more factual information studies in Indian history.

Raising well historians, one of the important figures of Indian history, is also vital. Particularly, while history departments in Turkey are educating researchers and historians for the current subject, conducting the meticulous field study and developing basic data of archaeology with the material resources will provide studies with quality and great impact.

As a consequence of being pertinent of the history to human and human's having a complex and multi-lateral world, to benefit from different disciplinaries in studies which carried out about the region, will bring direction to more different researches.

Peer-review: Externally peer-reviewed.

Conflict of Interest: The author has no conflict of interest to declare.

Grant Support: The author declared that this study has received no financial support.

Hakem Değerlendirmesi: Dış bağımsız.

Çıkar Çatışması: Yazar çıkar çatışması bildirmemiştir.

Finansal Destek: Yazar bu çalışma için finansal destek almadığını beyan etmiştir. 


\section{References}

Adıvar, Halide Edip. Hindistan 'a Dair (Inside India). İstanbul: Can Sanat Yayınları, 2014.

Ahmed Aziz. Siyasi Tarihi ve Müesseseleriyle Delhi Türk Imparatorluğu (Turkish Sultanate of Delhi with Its Political History and Institutions). İstanbul: Kervan Yayınları, 1949.

Hindistan'da İslam Kültürü Çalışmaları (Islamic Culture Studies in India). (Trans. Latif Boyac1). İstanbul: İnsan Yayınları, 1995.

Akbulut, Dursun Ali. "Illkçağda Soğdia ve Baktria ile Hindistan İlişkileri”, (Indian Relations with Sogdiana and Bactria in the First Age), Tarihte Türk-Hint Ilisskileri Sempozyumu Bildirileri, (31 November-1 October 2002). Ankara: Türk Tarih Kurumu Yayınları (TTK), 2006, 1-9.

Akbulut, Uğur. Hindistan Yolu ve İngilizler (Indian Way and the British). Konya: Çizgi Yayınları, 2016.

Akınc1, Halil. "Türk-Hint İlişkileri Sempozyumu” (Turkish-Indian Symposium), Tarihte Türk-Hint İlişsileri Seтровуити Bildirileri (25-28 June 2007), Ankara: TTK Yayınları, 2008, 19-23.

Akmal, N. Ayyubi. "Hind Kültürü Üzerinde Müslüman Türk Tesirleri” (Effects of Muslim-Turks on Indian Culture), İslam Tetkikleri Enstitüsü 3-4 (1966): 205-210.

"Hindistan Türklere Neler Borçludur?" (What does India owe to Turks?). İslam Araştırmaları Enstitüsü, Aligarh Müslüman Üniversitesi (Trans. Nejat Kaymaz) Ankara Üniversitesi Dil ve Tarih-Coğrafya Fakültesi (DTCF) Tarih Araştırmaları Dergisi, $2 / 2$ (1964): 2.

Armutlu, Sadık. "Gazneliler ve Selçuklular Döneminde Edebi Gelenek" (Literary Tradition during the Ghaznavids and Seljuk Period), Türkler Ansiklopedisi. V (2002): 872-879.

Ataöv, Türkkaya. Hindistan Siyaset Yazıları (Indian Political Writings). Ankara: Güzeliş Ofset, 2002.

Keşmir, Hindistan ve Komşuları (Kashmir, India and Neighbours). (Trans. Funda Keskin Ata- Elif Ağaoğlu). Ankara: TTK Yayınları, 2014.

Atay, Faik Rıfkı. Hind (India). İstanbul: Semih Lütfi Kitabevi, 1944.

Bâbür, Zahiruddin Muhammed. Bâbür, Vekâŷ̂: Bâbür'ün Hâtırâtı, (Babur's Memoirs, Babur-Nama). (Trans. Reşit Rahmeti Arat). Ankara: TTK Yayınları, 1987.

Barthold, V. Vladimiroviç. Moğol İstilasına Kadar Türkistan (Turkestan Down to Mongol Invasion). (Ed. Hakkı Dursun Yıldız). Ankara: TTK Yayınları, 1990.

Bayur, Y. Hikmet. Hindistan Tarihi İlk çağlardan Gurkanlı Devleti'nin Kuruluşuna Kadar. I (History of India, from the First Ages until the Establishment of the State of Gurkanid, I). Ankara: TTK Yayınlar1, 1946.

. Hindistan Tarihi Gurkanlı Devleti'nin Büyüklük Devri, II, (History of India, the Greatness of the State of Gurkanid State, II). Ankara: TTK Yayınları, 1947.

. Hindistan Tarihi Nadir Şah Afşar 'in Akınından Bağımsızlık ve Cumhuriyete Kadar. III, (History of India, Independence from the Influence of Nadir Shah Afshar and Republic, III). Ankara: TTK Yayınları, 1987.

Bıyıklığlu, Tevfik. Hint Tarihi (History of Indian). İstanbul: Devlet Matbaası, 1931.

Bıyıktay, Halis. Timurlular Zamanında Hindistan Türk Imparatorluğu (Indian Turkish Empire during Timurids). Ankara: Türk Tarih Kurumu Yayınları, 1941.

Bilkan, Ali Fuat. Sebk-i Hindi ve Türk Edebiyatında Hint Tarzı (Sabk-i Hindī and Indian Sytle in Turkish Literature). İstanbul: 3F Yayınları, 2007.

Sultan 'ın Dini (The Religion of the Sultan). İstanbul: Timaş Yayınları, 2015. 
"Hindistan Kütüphanelerindeki Türkçe El Yazmaları ve Hindistan'da Türkçe” (Turkish Manuscripts at Indian Libraries and Turkish in India), Tarihte Türk-Hint İlişkileri Sempozyumu Bildirileri, (31 October-1 November 2002) Ankara: TTK Yayınlar1, 2006, 351-36.

Birışık, Abdulhamit. "Hint Alt-Kıtasında İslâm Araştırmalarının Dünü Bugünü: Kurumlar, İlmî Faaliyetler, Şahıslar, Eserler" (Past and today of Islamic studies: Institutions, Scientific Activities, Characters, Works), Dîvân: Disiplinlerarası Çalışmalar 17 (2004): 1-62.

Bakuleva, B. R.Avakova ve J. Abeldayev. “Türk Kültürünün Hindistan Uygarlığına Etkisi” (The Effect of Turkish Culture on Indian Civilization ), Türk Dünyası Íncelemeleri Dergisi, XII/1, İzmir, (2012): 441-454. Cöhce, Salim. Delhi Türk Sultanlı̆ğ Tarihi (History of Dehli Turkish Sultanate). Malatya: 2001.

. "Delhi Türk Sultanlığında Memlûk Sistemi” (Mamluk System in Turkish Sultanate of Delhi), Milletlerarası Türkoloji Kongresi, (21-26 September 1987) İstanbul, 1987.

“Delhi Türk İmparatorluğu’nda Sultan Şemseddîn İltutmuş’un Kırk Kölesi: Çihilganilerin Kimlikleri ve Oynadıkları Roller” (Fourty Slaves of Sultan Shams Al-Din Iltutmish in Turkish Sultanate of Delhi: The Chilgani's Identities and Roles They Played), Beşinci Milletlearası Türkoloji Kongresi (23-28 September) İstanbul, 1985.

"'Hindistan'da Türk Askerî Aristokrasisi” (Turkish Military Aristocracy in India), X.

Türk Tarih Kongresi, (22-26 September) Ankara: TTK, 1986.

“XIII ve XIV. Yüzyılda Hindistan’da Türk Hâkimiyeti” (Turkish Domination in India in XIIIth and XIVth Centuries), (İnönü Üniversitesi Araştırma Projesi) (May 1995-November 1996) Malatya, 2001.

“Hindistan’da Türk Kültürünün Gelişimi ve Hint Kültürüne Tesiri” (International

Development of Turkish Culture in India and Its Effect on Indian Culture). VI. Uluslararası Türk Kültürü Kongresi; Türk Kültürünün Dünya Kültürüne Etkileri, (21-26 May) Ankara: TTK, 2005.

"İlk Çağda Hindistan'da Türk Varlığı” (Turkish Existence in India in the First Age), Hindistan Türk Tarihi Araştırmaları Dergisi I / 1 (January/June) (2001): 8-19.

. "Gazneli Mahmud Dönemine Kadar Hindistan’da Türk Varlığı” (Existence of Turks until The Period of Mahmud of Ghazni in India), Erdem (Aydın Sayılı Özel sayısı) IX/27, (1996): 981-987.

“Delhi Sultanlığı ve Racalar” (The Dehli Sultanate and Rajas), Hindistan Tarihi Araştırma Konseyi Türk ve Hint Çalışmaları Uluslararası Semineri: Bir Değerlendirme (9-11 February 2005): 1-18.

. "Hindistan'da Türk Egemenliği: Kushans ve Akhunlar (Turkish Sovereignty in India:

Kushans and Akhunlar). Türkler Ansiklopedisi. I: 815-820, (Ed. H.C. Güzel vd.), Ankara: Yeni Türkiye Yayınları, 2002.

" "Gaznelilerin Hindistan Hâkimiyeti” (The Ghaznavid Empire of India), Türkler Ansiklopedisi. IV: 522-525, (Ed. H.C. Güzel vd.) Ankara: Yeni Türkiye Yayınları, 2002.

“'Hindistan'da Kurulan Türk Devletleri” (Turkish States Established in India), Türkler Ansiklopedisi. VIII: 689-730, (Ed. H. C. Güzel vd.), Ankara: Yeni Türkiye Yayınları, 2002.

"Development of Turkish Culture in India and its Effect on Indian", Culture International

6th Turkish Culture Congress; Effects of Turkish Culture on World Culture. (21-26 May) Ankara, 2005.

"Büyük Orta Doğu Projesi Bağlamında Hindistan ile Orta Doğu Arasındaki Tarihî

Bağlar ve Güncel İlişkiler” (Historical Linkages Between India and Middle Asia in the Context of Greater Middle East Initiative and Current Relations), Akademik Bakıs, II/III, (2008): 65-80. 
. "Türk İstiklal Mücadelesi ve Hindistan" (Turkish Struggle for Independence and India). Tarihte Türk-Hint Illişkileri Sempozyumu Bildirileri, (31 Ekim-1 Kasım 2002) Ankara: TTK Yayınları, 2006, 127-215.

"Kalaç Sultanlığgı" (Sultanate of Khaljis). Tarihte Türk-Hint İlişkileri Sempozyumu Bildirileri, (25-28 January 2007), Ankara: TTK Yayınları, 2008, 77-91.

“Kutbeddin Aybeg (1206-1210)'s Life and Personality, Founder of Turkish Sultanate of Delhi”. XIth Turkish History Congress, (5-9 September 1990), Ankara: TTK Yayınlar1, 1990, 42.

" "Delhi Türk Sultanlığının Kurucusu Kutbeddin Aybeg'in Hayatı ve Şahsiyeti” (Kutbeddin Aybeg's -1206-1210- Life and Personality, Founder of Turkish Sultanate of Delhi). Firat Üniversitesi Ilahiyat Fakültesi Dergisi, (2010): 13-24.

Cûzcâni. Minhâc-1 Sirâc el, Tabakât-i Nâsirî. (Trans. Mustafa Uyar), İstanbul: Ötüken Yayınları, 2016.

Çağdaş, Kemal. Hint Eski Çă̆ Kültür Tarihine Girişs (Introduction to the History of Indian Ancient History). Ankara Üniversitesi, Ankara: DTCF Yayınları, 1974.

Demirel, Şengül. "Hindistan'da Türk İzleri”, (Turkish Traces in India). ICANAS 38, International Congress of Asian and North African Studies), Ankara: Atatürk Kültür, Dil ve Tarih Yüksek Kurumu Yayınları, 2009.

Doğrul, Ömer Rıza. Ekber Ekber Bir Türk Dâhisi (Ekber A Turkish Genius). İstanbul: Yüksel Yayınevi, 1944.

Duğlat, Mirza Muhammad Haydar. Tarih-i Reşhidî (Tarikh-i Rashidi). (Trans. Osman Karatay), İstanbul: Selenge Yayınları, 2006.

Durak, Neslihan. Hindistan'a Kuzeyden Yapılan Seferler (Military Campaigns to India from North). Ankara: ASAM Yayınları, 2000.

"Hindistan'da Saka, Kuşan ve Akhunlar" (Scythians-Sakas, Kushans and White Huns in India). Tarihte Türk-Hint İlişkileri Sempozyumu Bildirileri, (25-28 June 2007), Ankara: TTK Yayınları, 2008, 139-145.

Ertaylan, İsmail Hikmet. Âdilşâhiler: Hindistan'da Bir Türk-İslam Devleti (Adil-Shahs: A Turkish-Islamic State in India). İstanbul: Sermet Yayınları, 1953.

Farooqi, SN. R. "Mughal India and the Ottoman Empire: A Study in Early Modern Diplomacy and Diplomatic Procedure", Tarihte Türk-Hint İlişkileri Sempozyumu Bildirileri, (25-28 June 2002), Ankara: TTK Yayınları, 2006, 85-127.

Galip, Mübarek. Hindistan'da Türkler (Turks in India). (Trans. Saadettin Y. Gömeç), Ankara: Berikan Yayınevi, 2013.

Grenard, Fernand. Babür (Babur). (Trans. Orhan Yüksel), İstanbul: Milli Eğitim Basımevi, 1971.

Gülbeden. Hümâŷ̂nnâme (Humayun-Nama). (Trans. Abdürrab Yelgar), Ankara: TTK Yayınları, 1944.

Haqqi, S. A. H. Hindistan'daki Türk Tesiri İlk Dönem. (Turkish Impact in India the First Phase). (Trans. Y. Tekin Kurat), Ankara: Orta Doğu Teknik Üniversitesi (ODTÜ) Yayınevi, 1984.

Kadîm, Nevres-i. Târih-i Selim Shah (Remembrance of Cihangir Shah). (Trans. Fahri Ünan), Ankara: TTK Yayınlar1, 2013.

Kafesoğlu, İbrahim. Müslüman Türk Devletleri Tarihi (History of Muslim Turkish States). İstanbul: İslâm Tarih, Sanat ve Kültürünü Araştırma Vakfı, 1999.

Kâhya, Esin. “İlkçağda Hindistan-Türk Düşüncesi Arasındaki İlişkiler” (Relations Between Turkish-Indian thought in the First Age). Tarihte Türk-Hint Illişkileri Sempozyumu Bildirileri, (31 Ekim-1 Kasım 2002) Ankara: TTK Yayınları, 2006, 257-275. 
Keleşyılmaz, Vahdet. Teşkilâtı Mahsûsa'nın Hindistan Misyonu (1914-1918), (Indian Mission of Teskilat-l Mahsusa -Special Organization- 1914-1948). V/XV, Ankara: Atatürk Araştırma Merkezi Yayınları, 1999.

Khan, A. R. "Matrix of Autobiography: Some Obversations on Babur's Memories", Tarihte Türk-Hint Illişkileri Sempozyumu Bildirileri (25-28 June 2002), Ankara: TTK Yayınları, 2006, 73-85.

Konukçu, Enver. Kuşan ve Akhunların Tarihi (History of Kushans and White Huns). Ankara: Atatürk Üniversitesi Yayınlar1, 1973.

" "Hindistan'da Devlet Kuran Altaylı Kabilelerden Hunlar" (Huns Who Founded State in India, from Altaic Tribes). XVI. Milletlerarasl Altaistik Kongresi (1973) Ankara, 1979.

“Hindistan’daki Türk Devletleri” (Turkish States in India). Islam Ansiklopedisi. IX: 63-73. İstanbul, 1989.

"Kalaç Sultanı Ala ed-din Muhammed Şah ve Onun Hind Siyaseti” (Sultan Ala al-Din Muhammad Shah of Khaljis and His Indian Policy). VIII. Türk Tarih Kongresi Tebliğleri, Ankara: TTK Yayınlar1, 1981, 793-798.

"Dehli Kalaç Sultanlığının Kuruluşu” (Establishment of Khaljis Sultanate of Dehli). IX. Türk Tarih Kongresi Tebliğleri, Ankara: TTK Yayınları,1988, 587-597.

."Hind Kaynaklarında Hunlara Dair Bazı Kayıtlar" (Some Records for Huns in Indian Sources). Atatürk Üniversitesi Edebiyat Fakültesi Dergisi, Erzurum: Atatürk Üniversitesi Yayınları, $1983,5$. . “Önsöz” (Presentation). Hindistan Türk Tarihi Araştırmaları Dergisi, I/I, (January-June 2001): 1-2, Malatya.

."Hindistan'daki Türk Devletleri” (Turkish States in India). Büyük İslam Tarihi. I-XV, (Ed. H. Dursun Yıldız), İstanbul: Çă̆ Yayınları, 1989, 63-71.

"Babürlüler, Hindistan'daki Temürlüler" (Baburids: Timurids in India). TürklerAnsiklopedisi.

VIII: 1321-1345, Ankara, 1991.

. "Babürlüler” (Baburids). Diyanet İslam Ansiklopedisi. IV: 397-405, İstanbul, 1990.

“Hindistan’daki Türk Devletleri” (Turkish States in India). Tarihte Türk-Hint Illişkileri

Sempozyumu Bildirileri, (31 October- 1 November 2002) Ankara: TTK Yayınları, 2006, 67-73.

“Ekber” (Akbar). Diyanet Íslam Ansiklopedisi. X: 542-544, İstanbul, 1994.

. “XII-XVI. Yüzyıllarda Hindistan'da Türk Kurucular ve Hanedanlar” (Turkish Founders and Dynasties in XII-XVIth centuries in India). Erdem, IX/27 (1994): 1177-1183, Ankara.

“Hindistan’daki Kalaçların Başkentleri: Lakhnauti, Delhi, Dhar ve Mândû” (Capital Cities of Khaljis in India, Lakhnauti, Delhi, Dhar ve Mândû). Tarihte Türk-Hint İlişkileri Sempozyumu Bildirileri, (25-28 Haziran 2007), Ankara: TTK Yayınları, 2008, 145-173.

Kortel, S. Haluk. Delhi Türk Sultanlı̆̆ında Teşkilat 1206-1414 (Organization in Turkish Sultanate of Delhi 1206-1414). Ankara: TTK Yayınları, 2006.

Köprülü, Mehmet Fuat. "Gazneliler Devrinde Türk Şiiri” (Turkish Poetry during the period of Ghaznavids). Türk Dili ve Edebiyatı Hakkında Araştırmalar, (1934): 2-32, İstanbul.

Kulke, Herman, D. Rothermund. Hindistan Tarihi (History of India). (Trans. Müfit Gunay), Ankara: İmge Yayınlar1, 2001.

Kutlutürk, Cemil. Hint Düşüncesinde İslam Alglsı (Perception of Islam in Indian Thought). İstanbul: Dergâh

Yayınları, 2019. 
"Müslüman Türklerin Hint Dili ve Edebiyatına Katkısı", (Contribution of Muslim Turks to Indian Language and Literature), BİLIG Türk Dünyası Sosyal Bilimler Dergisi 87 (2018): 33-58.

Melzig, Herbert. Büyük Türk Hindistan Kapılarında: Kanunî Sultan Süleyman Devrinde Amiral Hadım Süleyman Paşa'nın Hind Seferi (Great Turkish Gate of the Indian Salt Sultan Suleiman the Magnificent in the era of Suleyman Pasha's Hind Expedition). İstanbul: Selami Sertoğlu Yayınları, 1943.

Merçil, Erdoğan. Gazneliler Devleti Tarihi (History of Ghaznavids State). Ankara: TTK Yayınları, 1989.

- Afganistan ve Hindistan'da Bir Türk Devleti Gazneliler (Ghaznavids, a Turkish State in Afghanistan and India), İstanbul: Bilge Kültür Sanat Yayınları, 2014.

“Gazneliler ve Hindistan” (Ghaznavids and India). Tarihte Türk-Hint İlişkileri Sempozyumu Bildirileri (31 Ekim- 1 Kasım 2002) Ankara: TTK Yayınları, 2006, 57-63. -. "Gazneliler" (Ghaznavids). TürklerAnsiklopedisi. IV: 479-508.

. Müslüman Türk Devletleri (History of Muslim Turkish States). Ankara: TTK Yayınları, 2006.

. "Gazneli Ordusundaki Hintli Askerler" (Indians in the Ghaznavids Army). Belleten,

LXX, (2006): 259, Ankara.

Meriç, Cemil. Hint Edebiyatı (Indian Literature). İstanbul: Dönem Yayınları, 1964.

Mughul, M. Yakub. Kanunî Devri: Osmanlıların Hint Okyanusu Politikası ve Osmanl-Hint Müslümanları Münasebetleri: 1517-1538 (Period of Sultan Suleyman the Magnificent: Ottoman Policy in Indian Ocean and Ottoman-Indian Muslims Relations: 1517-1538). İstanbul: Fetih Yayınevi, 1974.

Orkun, Hüseyin Namık. Yeryüzünde Türkler (Turks Over the World). İstanbul: Çınaraltı Yayınları, 1944.

Oruç, Cihan. "Şah Cihan Döneminde Babürlü-Safevi Diplomatik İlişkileri” (Baburid-Safavid Diplomatic Relations during Shah Jahan), Vakanüvis-Uluslararası Tarih Araştırmaları Dergisi, 2/2 (2017): 191-205.

Ortaylı, İlber. “19. Asırdan Zamanımıza Hindistan Üzerine Türk Seyhatnameleri” (Turkish Travels on India from the $19^{\text {th }}$ Century to Our Times). Ankara Üniversitesi Siyasal Bilgiler Fakültesi Dergisi, 3/47, (1992): 271-277.

Özcan, Azmi. “Osmanlı Coğrafyasında Hintli Bir Şeyh: Muttaki el-Hindî” (An Indian Sheikh in Ottoman Geography, Muttaqi al-Hindi). Tarihte Türk-Hint Illişkileri Sempozyumu Bildirileri, (25-28 June 2007) Ankara: TTK Yayınları, 2008, 173.

Pan-İslamizm, Osmanl Devleti, Hindistan Müslümanlarl ve Ingiltere (1877-1924), (PanIslamism, Ottoman Empire, Indian Muslims and England 1877-1924). Ankara: İSAM, 1997.

. "Osmanl1-Hindistan Münasebetleri” (Ottoman-Indian Relations İslam). Íslam Ansiklopedisi. XVIII: 81-85, 1998.

Mızrak, Egemen Çağrı. M.Ö. 7. Yüzyıldan M.S. 6. Yüzyılın Ortalarına Kadar Batı Türkistan ve Kuzey Hindistan'daki Bozkır Kavimleri (The Steppe Peoples of Western Turkistan and Northern India from the $7^{\text {th }}$ Century BC to the Mid-6t ${ }^{\mathrm{h}}$ Century). İstanbul: Ötüken Neşriyat, 2017.

Mohapatra, A. K. "Bridge to Anatolia Indo-Turkish Relations in Different Phases of History". Tarihte Türk-Hint Ilişkileri Sempozyumu Bildirileri (25-28 June 2007), Ankara: TTK Yayınları, 2008, 23-31.

Özdemir, Ahmed. “Ekber Şah’ın Din Modeli ve İmam-1 Rabbani” (Akbar Shah’s Religion Model and Imam Rabbani). Altınoluk Dergisi 188, (2001): 21.

Palabıyık, M. Hanefi. "Hindistan'da Gazneli-Türk Hâkimiyeti” (Ghaznavid-Turkish Domination in Indian History). Turkish-Indian Relations Symposium Proceedings in History, (25-28 June 2007), Ankara: TTK Yayınları, 2008, 91-129. 
"Hindistan Tarihinde ve Hint Kültüründe Müslüman Türkler" (Muslim Turks in Indian History and Indian Culture), EKEV Akademi Dergisi 11/33, (2007): 67.

. "Hint Dinleri ve İslam” (Indian Religions and Islam). Tarihte Türk-Hint İlişkileri Sempozyumu Bildirileri (31 October-1 November 2002), Ankara: TTK Yayınlar1, 2006, 275-339.

Şahin, H. Hilal. “Osmanlı-Hint İlişkilerine Genel Bir Bakış XV-XVIII. Yüzyıl” (A General Outlook on Ottoman-Indian Relations-XV-XVIII' ${ }^{\text {th }}$ Century), Akademik Tarih ve Düşünce Dergisi 2/6, (2015): 59-77. "Babürlü Sultanı Gülbeden Begüm” (Baburid Sultana: Gulbadan Begum). Akademik Tarih ve Düşünce Dergisi 3/8, (2016): 1-22.

. "Bir İngiliz Türk Savaşında Hintli Askerler: Kût'ül-Amâre'de Sosyal Bir Dram” (Indian

Soldiers in a War of British-Turkish: A Social Tradegy in Kut-al Amara), Akademik Tarih ve Düşünce Dergisi 4/13 (2017): 1-23.

“"Hintli Bir Alimin Tarihte Yöntembilim Çalışması: Ziyâeddin Berenî’nin Târîh-î Fîrûzşâhî Eserinin Modern Tarih Yazıcılığı Açısından Değeri” (An Indian Scholar's Methodology Study in History: Value of The Work of Tarikh-i Firoz Shahi by Ziaud Din Barani in Terms of Modern Historiography). XVIII. Türk Tarih Kongresi, (1-5 October 2018) Ankara: 2018.

Öztuna, Yılmaz. İslam Devletleri Devletler ve Hanedanlar I-V (Islamic States States and Dynasties I-V). Ankara: Kültür Bakanlığı Yayınları, 1989.

Rasonyi, BL. Dünya Tarihinde Türklük (Turkishness in World History). Ankara: İdeal Matbaa, 1942.

Saltık, Ekrem. Güney Asya ve Uzak Doğu’da Osmanlı İzleri (Ottoman Traces in South Asia and Far East). İstanbul: Nesil Basım Yayın Gıda Ticaret ve Sanayi A.Ş., 2011.

Tan, Mehmet Turhan. Hint Denizinde Türkler (Turks in Indian Sea). İstanbul: Çağrı Yay., 2010.

Terzioglu, Arslan. “Gazneliler Devrinin Büyük Türk Alimi Al-Bîrûnî (973-1051)” (Al-Birunî, Great Turkish Scholar of Ghaznavid Period- 973-1051). Haseki Tıp Bülteni Tıp Bülteni, Ayrı Bask1, 12, (1974): 3.

Tezcan, Mehmet. "Kuşanlar, Akhunlar ve Eftalitler” (Kushans, White Huns and Ephthalites). Tarihte TürkHint İlişkileri Sempozyumu Bildirileri, (31 Ekim- 1 Kasım 2002), Ankara: TTK Yayınları, 2006, 9-57.

Togan, Z. Velidi. Umumi Türk Tarihine Giriş (Introduction to General Turkish History). İstanbul: İsmail Akgün Matbaası, 1946.

"Eftalit Devletini Teşkil Eden Kabilelere Dair" (On the Tribes Forming the State of Ephthalites). Atatürk Üniversitesi Fen Edebiyat Fakültesi Araştırma Dergisi, XIII/1, (1985): 58-63, Erzurum.

Turan, Refik ve Fatma Ahsen Turan. “Hindistan’a Yapılan Bir Araştırma Gezisi ve Balabanlar” (A Research Trip to India and the Balaban). Gazi Üniversitesi, Türk Kültürü ve Hacı Bektaş Veli Araştırma Dergisi, 35, (2005): 113-144.

Türkmen, Erkan. Sultan Raziye (Sultan Razia). İstanbul: Nüve Kültür Merkezi Yayınları, 2007.

Türkmen, Fikret. "Hint-Türk Folklor Etkileşimi” (Indian-Turkish Folklore Interaction). Tarihte Türk-Hint İlişkileri Sempozyumu Bildirileri (31 October-1 November 2002), Ankara: TTK Yayınları, 2006, 339-351.

Vural, Suat. "Hindistan' da İngiliz Hâkimiyetinin Kurulması" (Establishment of British Domination in India). Tarihte Türk-Hint Illişkileri Sempozyumu Bildirileri (25-28 June 2007). Ankara: TTK Yayınları, 2008, 129-139.

Yetkin, S. Kemal. İslam Mimarisi (Islamic Architecture). Ankara: Ankara Üniversitesi Yayınları, 1963. 


\section{Thesis}

Aamir, A. Hafiz. Hindistan'da Son Türk Sultanı II. Bahadır Şah Zafer ve 1857 Bağımsızlık Savaşı (Bahadur Shah Zafar II, The Last Turkish Sultan in India and 1857 Independence War). Basılmamış Yüksek Lisans Tezi, Necmettin Erbakan Üniversitesi, Sosyal Bilimler Enstitüsü, Konya, 2017.

Alpargu, Mehmet. Diğer Kaynaklarla Göre Karşılaştırma Yolu ile Babürname'nin Türk Devlet Teşkilatı Bakımindan Değerlendirilmesi (Evaluation of Babürname in Terms of Turkish State Organization by Comparing with Other Source). Basılmamış Doktora Tezi, Ankara Üniversitesi, Sosyal Bilimler Enstitüsü, Ankara, 1983.

Atac, A. Cemile. Risaleler Savaşı (1807-1809): Doğu Hindistan Şirketi’nin Dinsel Hoşgörü Politikasina Karşı Misyonerlerin Tepkisi ile Ortaya Çıkan Önemli bir Kriz (War of Epistles 1807-1809: An Important Crise Arosen by Missionaries' Reaction against Religious Toleration Policy of East India Company). Basılmamış Yüksek Lisans Tezi, İhsan Doğramacı Bilkent Üniversitesi, Sosyal Bilimler Enstitüsü, İstanbul, 1998.

Cöhce, Salim. Şemsi Melikleri (Shamsi Maliks). Basılmamış Doktora Tezi, Fırat Üniversitesi, Elazığ, 1986.

Çağlayan, H. Hilal. Ekber Şah Döneminde Hindistan (1542-1605) (India During Akbar Shah-1542-1605). Basılmamış Yüksek Lisans Tezi, Ankara Üniversitesi, Sosyal Bilimler Enstitüsü, Ankara, 2005.

Eryılmaz, İsa. Hindistan'da Racputlar (Rajputs in India). Basılmamış Yüksek Lisans Tezi, Gaziosmanpaşa Üniversitesi, Tokat, 2011.

Güneri, Mukadder. Babür'ün Sosyal ve Kültürel Hizmetleri (Babur Shah's Social and Cultural Services). Basılmamış Doktora Tezi, Ankara Üniversitesi, Sosyal Bilimler Enstitüsü, Ankara, 2000.

Halıcı, A. Gülseren. Hindistan'da Kalıcı Türk İzleri (Permanent Turkish Traces in India). Basılmamış Doktora Tezi, Ankara Üniversitesi, Sosyal Bilimler Enstitüsü, Ankara, 1995.

Karakuş, Yasin. XIII ve XIV ${ }^{\mathrm{h}}$ yüzyllda Hindistan'da Türk Hâkimiyeti (The sovereignty of Turks in India in the XIII. and XIV Centuries). Basılmamış Yüksek Lisans Tezi, Trakya Üniversitesi, Sosyal Bilimler Enstitüsü, Edirne, 2015.

Keskin, Mustafa. İngilizlerin Hindistan’ ı Sömürgeleştirme Hareketleri (The British’s Colonization Movements of India). Basılmamış Yüksek Lisans Tezi, Hacettepe Üniversitesi, 2005.

Konukçu, Enver. Kalaç Sutanlığı (Khaljis Sultanate). Basılmamış Doktora Tezi, Atatürk Üniversitesi, 1977.

Kuş, Canan. XVI. Yüzyılda Ticarî Alanda Osmanl- Hindistan İlişkileri (Commercial Area Relationships Between Ottoman and India at 16th Century). Basılmamış Doktora Tezi, Fırat Üniversitesi, 2012.

Mujiburahman, Timur, Gazneli Devletinden Babürler Devletine Kadar Bölgede Kurulan Hükümdarlıklar (1206-1526) (The Indian Dynasties Established from the Ghaznawi's until the Baburid State 1206-1526). Basılmamış Yüksek Lisans Tezi, Selçuk Üniversitesi, Konya, 2012.

Öztoksoy, Özlem Nurben. 16-18. Yüzylllarda Osmanlı-Hint-Baburlu Kumaş Sanatlarının Etkileşimi (Interactions of Cloths Arts of Ottoman-Indian-Baburid of 16-18th Centuries). Doktora Tezi, İstanbul Üniversitesi, Sosyal Bilimler Enstitüsü, İstanbul, 2007.

Şahin, H. Hilal. Ekber Şah ve Dinî Reformu (Ekber Shah and Religious Reform). Basılmamış Doktora Tezi, Ankara Üniversitesi Sosyal Bilimler Enstitüsü, Ankara, 2014.

Şen, Mesut. Gazi Zahirüddin Muhammed Babur, Baburname Giriş-metin (Kabil ve Hindistan bölümleri). Basılmamış Doktora Tezi, Marmara Üniversitesi, İstanbul, 993. 
Tan, Muharrem. Hindistan'ın Bölünmesi ve Hint Müslümanlart: 1858-1947 (Division of India and Indian Muslims: 1858-1947). Yüksek Lisans Tezi, Marmara Üniversitesi, İstanbul, 1999.

Turgut, Melahat Hande. Gupta Imparatorluğu: Hindistan'ın Altın Çă̆l (M.S. 4-6.yy.) (Gupta Empire: The Golden Age of India) (4-6th centuries a.d.). Basılmamış Yüksek Lisans Tezi, Ankara Üniversitesi, 2009.

\section{Web Sites}

http://www.tkaed.org/ (Accessed on: 13.03.2019) 